\title{
Design, Synthesis and Anticancer Biological Evaluation of Novel 1,4-Diaryl- 1,2,3-triazole Retinoid Analogues of Tamibarotene (AM80)
}

\author{
Mariana A. A. Aleixo, ${ }^{a}$ Taís M. Garcia, ${ }^{a}$ Diego B. Carvalho, ${ }^{a}$ Luiz H. Viana, ${ }^{a}$ \\ Marcos S. Amaral, ${ }^{a}$ Najla M. Kassab, ${ }^{a}$ Marilin C. Cunha, ${ }^{b}$ Indiara C. Pereira, ${ }^{b}$ \\ Palimécio G. Guerrero Jr., ${ }^{c}$ Renata T. Perdomo, ${ }^{b}$ Maria F. C. Matos ${ }^{b}$ and \\ Adriano C. M. Baroni $* a$ \\ ${ }^{a}$ Laboratório de Síntese e Química Medicinal (LASQUIM) and \\ ${ }^{b}$ Laboratório de Biologia molecular e Cultura de Células, \\ Faculdade de Ciências Farmacêuticas, Alimentos e Nutrição (FACFAN), \\ Universidade Federal do Mato Grosso do Sul (UFMS), 79070-900 Campo Grande-MS, Brazil \\ 'Departamento de Química e Biologia (DAQBi), \\ Universidade Tecnológica Federal do Paraná (UTFPR), 80230-901 Curitiba-PR, Brazil
}

\begin{abstract}
We report herein the design and synthesis via click chemistry of twelve novel triazole retinoid analogues of tamibarotene (AM80) and the evaluation of their anticancer activities against six cancer cell lines: HL60, K562, 786, HT29, MCF7 and PC3. Among the synthesized compounds, two were more potent than tamibarotene against solid tumor cells, and one of them had similar potency to tamibarotene against HL60 cells. The bioisosteric exchange between the amide group and the 1,2,3-triazole core in the retinoid agent tamibarotene (AM80) reported in this work is a valid strategy for the generation of useful compounds against cancer.
\end{abstract}

Keywords: 1,2,3-triazole retinoids, tamibarotene, click chemistry, bioisosterism, anticancer activities

\section{Introduction}

In recent years, cancers have been responsible for 8.2 million human deaths worldwide. ${ }^{1,2}$ The rising demand for effective and safer anticancer drugs has led several research groups to develop new strategies to synthesize a wide range of anticancer molecules and to evaluate their biological anticancer activities. ${ }^{2}$

Retinoids are class of chemical compounds that are derivatives of vitamin A with a large number of biological processes. ${ }^{3}$ Retinoids were originally developed to treat skin disorders, but these compounds have other potential therapeutic uses, such as in type II diabetes, viral infection, metabolic diseases, Alzheimer's disease, and, primarily, cancer, due to their effects on growth differentiation and apoptosis. ${ }^{3-5}$

The biological effects of retinoids result from their modulation of retinoic acid receptors (RARs) and retinoic $\mathrm{X}$ receptors (RXRs), each having three target

*e-mail: adriano.baroni@ufms.br subtypes: $\alpha, \beta$ and $\gamma^{3-5}$ RAR $\alpha$ receptor have important role in hematopoiesis. Agonists of RAR $\alpha$ receptor are used against acute promyelocytic leukemia (APL), and in the chemoprevention of estrogen receptor-positive (ER-positive) breast cancer cell line. Studies have showed that normal RAR $\beta$ signaling is important factor in the control of certain types of cancers. RAR $\gamma$ receptor, for instance, is important for the skin functioning and their agonists have been used in dermatology for the treatment of acne, pysoriasis and photodamaged skin. ${ }^{6} \mathrm{RXR}$ receptors have important role in metabolic diseases, as type II diabetes. Their agonists have also been used in the chemoprevention of breast cancer. ${ }^{6}$

Among several retinoid anticancer compounds, here we consider the pan-RAR agonists ATRA 1 (natural ligand) ${ }^{3-5}$ and TTNPB 2 (synthetic ligand), ${ }^{3-5}$ the pan-RXR agonist bexarotene $3,^{3-9}$ the selective RAR $\alpha$ receptor synthetic agonists AM80 4-9 and AM580 5, ${ }^{3-9}$ and UVI2007 6, an RAR $\beta$ agonist $^{10}$ (Figure 1).

The molecular structures of retinoids can be divided into three parts: a hydrophobic region, a linker unit, and 
<smiles>CC(/C=C/C1C(C)CCCC1(C)C)=C\C=C\C(C)=C\C(=O)O</smiles>
1<smiles>CC(C)(C)Oc1ccc2c(c1)C(C)(C)CCC2(C)C</smiles>

4<smiles>C/C(=C\c1ccc(C(=O)O)cc1)c1ccc2c(c1)C(C)(C)CCC2(C)C</smiles>

2<smiles>CC(C)(C)OC(=O)Nc1ccc(C(=O)O)cc1</smiles>

5<smiles>C=C(c1ccc(C(=O)O)cc1)c1cc2c(cc1OC(=O)[O-])C(C)(C)CCC2(C)C</smiles>

3<smiles>C/C(=C\c1ccc(C(=O)O)cc1Cl)c1ccc2c(c1)C(C)(C)CCC2(C)C</smiles>

Figure 1. Classical retinoids reported in the literature.

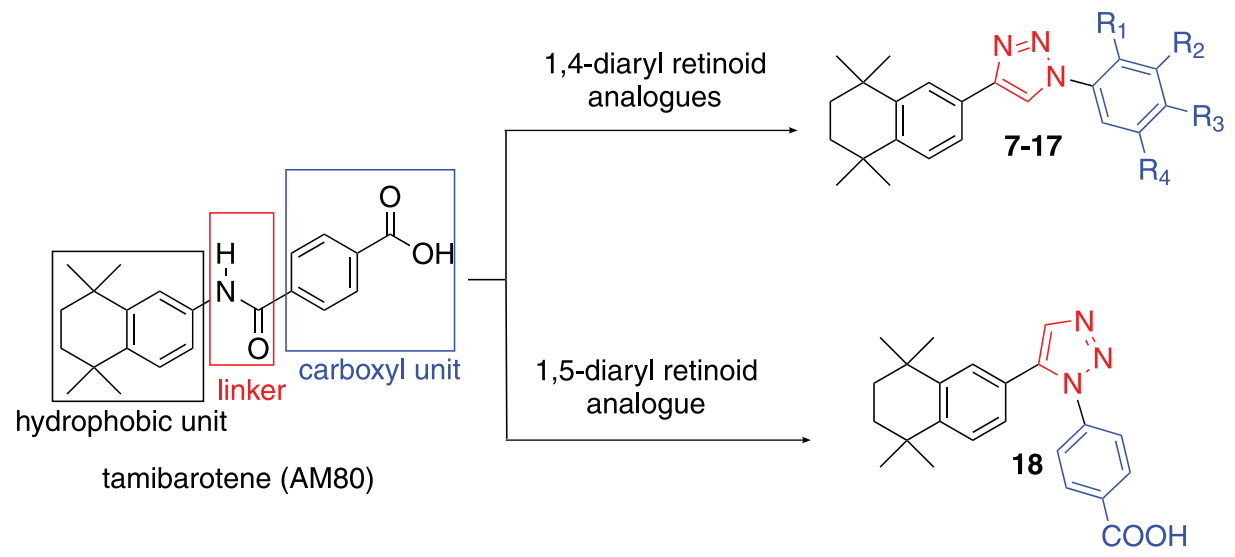

Figure 2. Design of retinoids containing a 1,2,3-triazole core.

a polar terminus (Figure 2). Molecular modifications ${ }^{3-10}$ can provide information about the structure-activity relationships (SARs) of these compounds.

The introduction of an amide group in the linker unit during the synthesis of tamibarotene (AM80) 4 and AM580 5 has yielded compounds with increased selectivity for the RAR $\alpha$ receptor, because the amide group does hydrogen bond interactions with the Ser232 residue.,7 In comparison, ATRA 1 and TTNPB 2 (Figure 1), which contains a nonpolar vinyl linker, do not interact with Ser 232; therefore, these compounds can be considered pan-RAR agonists. ${ }^{3,7}$

Compounds $\mathbf{1}$ and $\mathbf{4}$ were identified as effective anticancer agents for the treatment of acute promyelocytic leukemia (APL) by inducing the differentiation or inhibition of cell proliferation. As a consequence of these powerful biological effects, all-trans retinoic acid (ATRA) and tamibarotene $\mathbf{4}$ have been used clinically to treat APL. ${ }^{11-14}$ However, tamibarotene (AM80) 4 is ten times more potent than ATRA in inducing differentiation of HL60 and NB-4 cells, and it has lower drug resistance against APL cancer. ${ }^{13,14}$ Tamibarotene $\mathbf{4}$ has fewer side effects on the dermal epithelium than ATRA because it does not bind to the RAR $\gamma$ receptor. Although tamibarotene $\mathbf{4}$ being less toxic than ATRA, side effects still have limited its use in the long-term treatment against APL cancer. ${ }^{13,14}$

Considering our research group's interest in synthesizing novel anti-cancer agents, we focused our studies on the development of novel retinoid molecules based on the tamibarotene structure.

The compounds were designed using classical modification strategies, such as the use of bioisosterism (Figure 2). The 1,2,3-triazole rings are effective amide surrogates due to their strong dipole moments, their similarities in terms of distance and planarity, and also, as the amides, 1,2,3-triazole core can make hydrogen bonds. ${ }^{15} \mathrm{We}$ chose 1,2,3-triazole moiety because it have also been found in anticancer substances, ${ }^{16}$ and it is more metabolic stable than amines. ${ }^{15}$ Thus, we believe that novel 1,2,3-triazole retinoids designed herein, also may be a selective RAR $\alpha$ agonist as tamibarotene $\mathbf{4}$, and this approach may contribute to obtain new derivatives with improved anticancer activities.

The carboxylic acid unit was also modified to obtain SAR information for 7-17 (Figure 2). ${ }^{17}$ The unknown 1,5-diaryl-1,2,3-triazolic retinoid derivative $\mathbf{1 8}$ was designed with the goal of comparing its anticancer activities with those of compound 7 . 


\section{Results and Discussion}

To synthesize the 1,2,3-triazole core, it was used a click chemistry approach. ${ }^{18}$ Some important characteristics of click reactions in organic synthesis are their modular nature, high yields of products, broad scope, ability to isolate products without chromatographic methods, use of solvents with low toxicity, and stereospecificity, which makes these methods very useful in organic synthesis. ${ }^{18}$

Another important characteristic of the click chemistry approach in medicinal chemistry is the possibility to rapidly synthesize a library of compounds with broad structural diversification in order to obtain new molecules with improved biological activity. ${ }^{19}$

The synthetic procedures for obtaining compounds 7-9 are shown in Scheme 1. The construction of 1,2,3-triazole cores in click reactions depends on the reaction between two building blocks, terminal acetylenes and azides. ${ }^{18,19}$

The synthesis was initiated by the reaction of 2,5-dimethyl-2,5-hexanediol 19 with 37\% hydrochloric acid for $64 \mathrm{~h}$ at room temperature, generating 2,5-dichloro2,5-dimethyl hexane $\mathbf{2 0}$ in $85 \%$ yield (Scheme 1). ${ }^{6}$

Then, Friedel-Crafts alkylation of $\mathbf{2 0}$ with an excess of benzene 21 using $\mathrm{AlCl}_{3}$ as a catalyst provided 1,1,4,4-tetramethyl-1,2,3,4-tetrahydronaphthalene $\mathbf{2 2}$ in $82 \%$ yield, ${ }^{6,20}$ which was then reacted with an $\mathrm{NBS} / \mathrm{TsOH} / \mathrm{CH}_{3} \mathrm{OH}$ system for $48 \mathrm{~h}$ under reflux to produce bromotetrahydronaphthalene $\mathbf{2 3}$ (Scheme 1). ${ }^{21}$

Subsequently, a Sonogashira cross-coupling reaction between bromide 23 and 2-methyl-3-butyn-2-ol 24 using $\mathrm{PdCl}_{2}\left(\mathrm{PPh}_{3}\right)_{2}$ and $\mathrm{CuI}$ as cocatalysts and $\mathrm{Et}_{3} \mathrm{~N}$ as a base produced the acetylenic alcohol $\mathbf{2 5}$ in $81 \%$ yield. ${ }^{20,22}$

The retro-Favorskii reaction of $\mathbf{2 5}$ with $\mathrm{KOH}$ under reflux in toluene generated the terminal acetylene $\mathbf{2 6}$ with $70 \%$ yield..$^{20,22} \mathrm{Next}$, the aromatic azides $28 \mathrm{a}$-c were prepared by the reaction of aromatic amines 27a-c with $t$ - $\mathrm{BuONO} / \mathrm{TMSN}_{3}$ using the protocol reported by Moses and co-workers. ${ }^{23}$

1,3-Dipolar cycloaddition occurred when terminal acetylene $\mathbf{2 6}$ reacted with aryl azides $\mathbf{2 8 a}$-c using $\mathrm{CuSO}_{4}$. $\mathrm{H}_{2} \mathrm{O}$, sodium ascorbate and $\mathrm{CH}_{2} \mathrm{Cl}_{2} / \mathrm{H}_{2} \mathrm{O} 1: 1$ as the solvent, yielding the ester-triazole compounds 29a-c in 80 to $89 \%$ yield. ${ }^{24}$

Subsequent hydrolysis of 29a-c with $\mathrm{NaOH}$ in EtOH/THF produced triazole-carboxylic acid retinoids 7-9 with 78 to $95 \%$ yield (Scheme 1). ${ }^{25}$

The 1,2,3-triazole retinoid derivatives 10-16 with
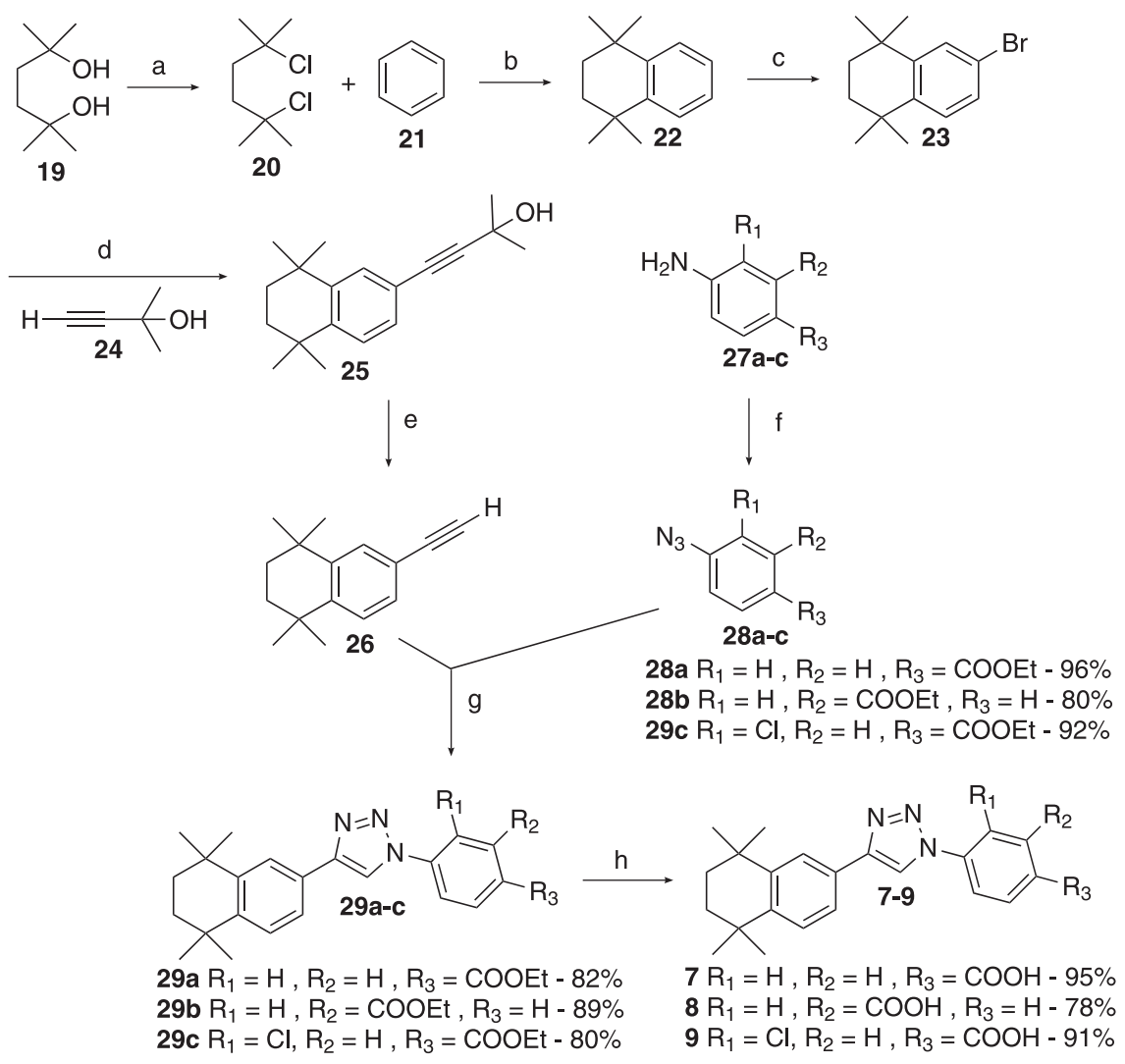

Scheme 1. Synthesis of 7-9. Reagents and conditions: (a) $\mathrm{HCl} \mathrm{37 \% ,} \mathrm{rt,} 64$ h, 85\%; (b) $\mathrm{AlCl}_{3}, \mathrm{reflux}, 48 \mathrm{~h}, 82 \%$; (c) $\mathrm{NBS}$, TsOH, $\mathrm{CH}$ OH, reflux, 48 h, 79\%; (d) 2-methyl-3-butyn-2-ol 24, $\mathrm{PdCl}_{2}\left(\mathrm{PPh}_{3}\right)_{2}, \mathrm{CuI}, \mathrm{Et}_{3} \mathrm{~N}$, reflux, $24 \mathrm{~h}, 81 \%$; (e) $\mathrm{KOH}$, toluene, reflux, $24 \mathrm{~h}, 70 \%$; (f) $t$ - $\mathrm{BuONO}, \mathrm{CH}{ }_{3} \mathrm{CN}, 15 \mathrm{~min}, 0{ }^{\circ} \mathrm{C}$; then $\mathrm{TMSN}_{3}$, rt, $5 \mathrm{~h}$; (g) $\mathrm{CuSO}_{4} .5 \mathrm{H}_{2} \mathrm{O}, \mathrm{CH}_{2} \mathrm{Cl}_{2} / \mathrm{H}_{2} \mathrm{O}$, sodium ascorbate, rt, $24 \mathrm{~h}$; (h) NaOH, EtOH/THF, 18 h. 


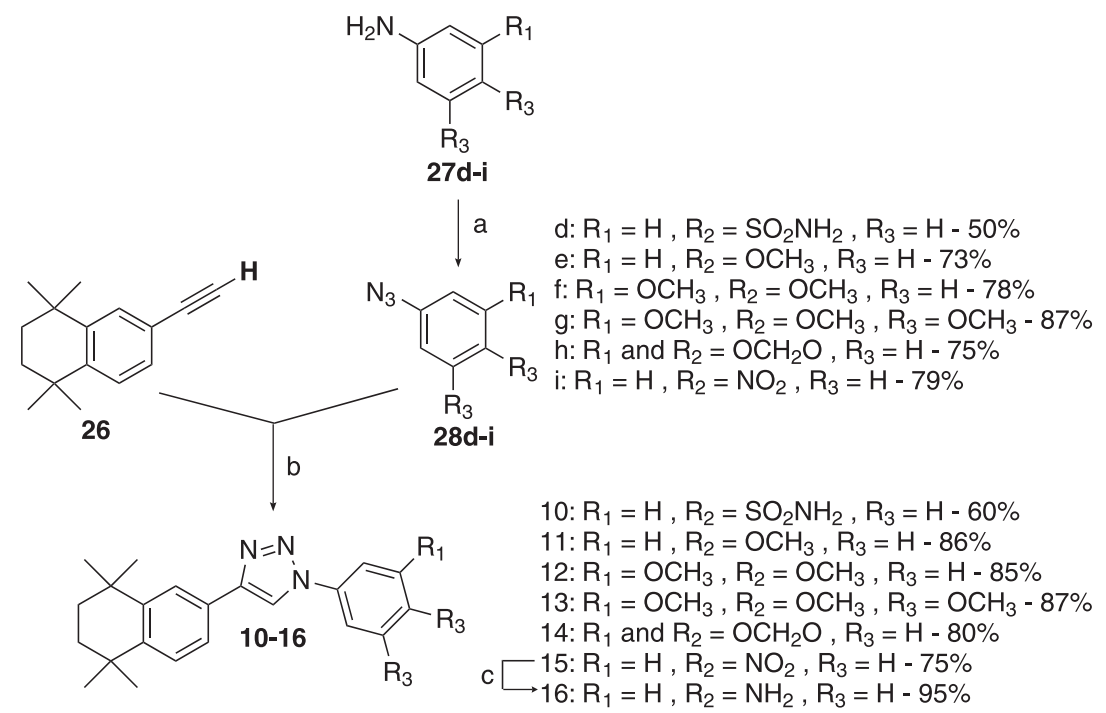

Scheme 2. Synthesis of 10-16. Reagents and conditions: (a) 27d-i; then $t$-BuONO, $\mathrm{CH}_{3} \mathrm{CN}, 15 \mathrm{~min}, 0{ }^{\circ} \mathrm{C}$; then $\mathrm{TMSN}_{3}, \mathrm{rt}, 5-24 \mathrm{~h}$; (b) $\mathrm{CuSO}_{4} \cdot 5 \mathrm{H}_{2} \mathrm{O}$, $\mathrm{CH}_{2} \mathrm{Cl}_{2} / \mathrm{H}_{2} \mathrm{O}$, sodium ascorbate, rt, $48 \mathrm{~h}$; (c) $\mathbf{1 5}$, then $\mathrm{Fe}^{\%} / \mathrm{CaCl}_{2} / \mathrm{EtOH}$, reflux, $48 \mathrm{~h}, 95 \%$.

molecular modification in the aryl carboxylic unit were synthesized by reaction of the terminal acetylene 26 and aryl azides $\mathbf{2 8 d - i}$ with different aromatic substitution patterns (Scheme 2).

The positional isomer $\mathbf{1 7}$ was also synthesized to compare its biological activity with that of $\mathbf{7}$ (Scheme 3). The synthesis of triazole $\mathbf{1 7}$ was initiated by nitration $\mathbf{2 1}$ of 1,1,4,4-tetramethyl-1,2,3,4-tetrahydronaphthalene $\mathbf{2 2}$, generating nitro tetrahydronaphthalene $\mathbf{3 0},{ }^{26}$ which was reduced to the corresponding amine $\mathbf{3 1}$ using the $\mathrm{Fe}^{0} / \mathrm{CaCl}_{2} / \mathrm{EtOH}$ system. ${ }^{27}$ Compound $\mathbf{3 1}$ was subsequently transformed into the corresponding tetrahydronaphthalene azide 32 in $78 \%$ yield using $t$-BuONO/TMSN 3 (Scheme 3). ${ }^{23}$

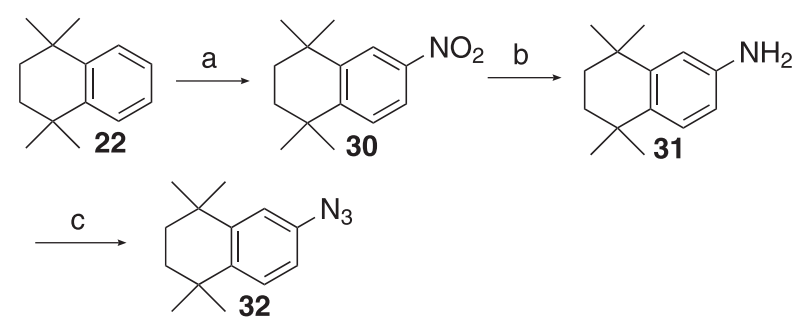

Scheme 3. Synthesis of 32. Reagents and conditions: (a) $\mathrm{HNO}_{3}, \mathrm{Ac}_{2} \mathrm{O}$, rt, $24 \mathrm{~h}, 92 \%$; (b) $\mathrm{Fe}^{0}, \mathrm{CaCl}_{2}, \mathrm{EtOH}$, reflux, $24 \mathrm{~h}, 75 \%$; (c) $t$-BuONO, $\mathrm{CH}_{3} \mathrm{CN}, 15 \mathrm{~min}, 0{ }^{\circ} \mathrm{C}$, then $\mathrm{TMSN}_{3}$, rt, $12 \mathrm{~h}, 78 \%$.

Next, the acetylene alcohol 34 was obtained in 90\% yield from the Sonogashira cross-coupling-type reaction between the ethyl 4-bromobenzoate $\mathbf{3 3}$ and 2-methyl3-butyn-2-ol 24 using a $\mathrm{PdCl}_{2}\left(\mathrm{PPh}_{3}\right)_{2} / \mathrm{CuI}$ system and $\mathrm{Et}_{3} \mathrm{~N}$ as base. ${ }^{20,22}$ The terminal acetylene $\mathbf{3 5}$ was obtained in $65 \%$ yield via retro-Favorski reaction of acetylene alcohol 34 with excess $\mathrm{NaH}$ in hexane under reflux for $48 \mathrm{~h}$ (Scheme 4). ${ }^{28}$

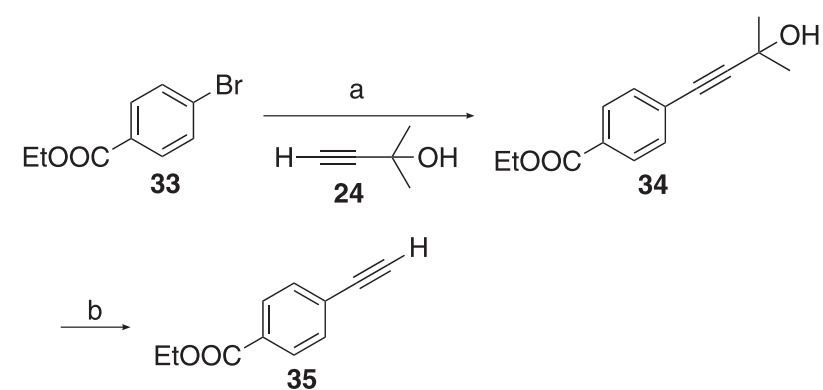

Scheme 4. Synthesis of 35. Reagents and conditions: (a) 2-methyl3-butyn-2-ol 25, $\mathrm{PdCl}_{2}\left(\mathrm{PPh}_{3}\right)_{2}, \mathrm{CuI}, \mathrm{Et}_{3} \mathrm{~N}$, reflux, 24 h, 70\%; (b) $\mathrm{NaH}$, hexane, reflux, $48 \mathrm{~h}, 65 \%$.

The 1,3-dipolar cycloaddition of aryl tetrahydronaphthalene azide $\mathbf{3 2}$ and terminal acetylene $\mathbf{3 5}$ afforded the ester triazole compound $\mathbf{3 6}$ in $85 \%$ yield. ${ }^{24}$ Hydrolysis reaction of $\mathbf{3 6}$ with $\mathrm{NaOH}$ generated the positional isomer $\mathbf{1 7}$ in $93 \%$ yield (Scheme 5). ${ }^{25}$

Finally, compound $\mathbf{1 8}$ was synthesized using Fokin's methodology ${ }^{29}$ by reaction between terminal acetylene $\mathbf{2 7}$ and azide ester 29a with 3 equiv. of potassium tert-butoxide in dimethyl sulfoxide (DMSO) in order to compare the anticancer activity of compound $\mathbf{1 8}$ with those of $\mathbf{7}$ and $\mathbf{1 7 .}$

Unlike Fokin and co-workers, ${ }^{29}$ an excess of $t$-BuOK was used, allowing one-pot preparation of compound $\mathbf{1 8}$ without requiring a deprotection step.

\section{Biological activity}

All triazole retinoid analogues synthesized were evaluated for antiproliferative activity (Table 1) against human leukemia cells (HL-60), chronic myeloid leukemia cells (K562), human renal cell carcinoma (786), colorectal 

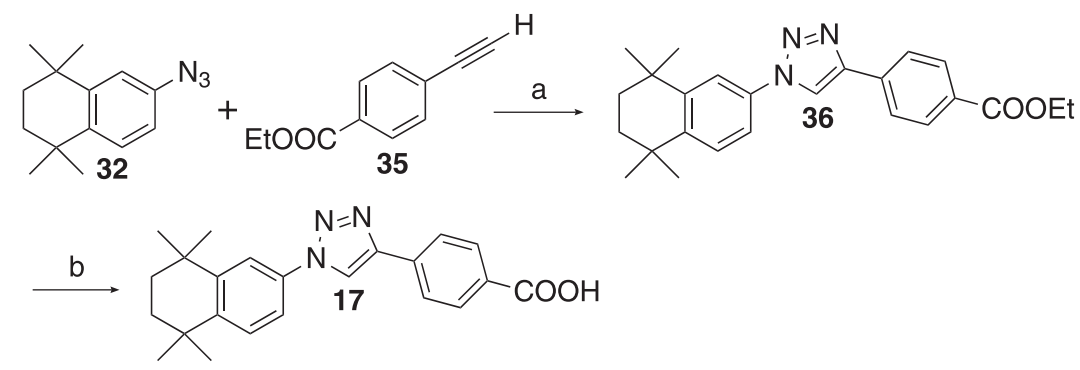

Scheme 5. Synthesis of 17. Reagents and conditions: (a) $\mathrm{CuSO}_{4} \cdot 5 \mathrm{H}_{2} \mathrm{O}, \mathrm{CH}_{2} \mathrm{Cl}_{2} / \mathrm{H}_{2} \mathrm{O}$, sodium ascorbate, rt, $48 \mathrm{~h}, 85 \%$; (b) NaOH, EtOH/THF, $18 \mathrm{~h}, 93 \%$.

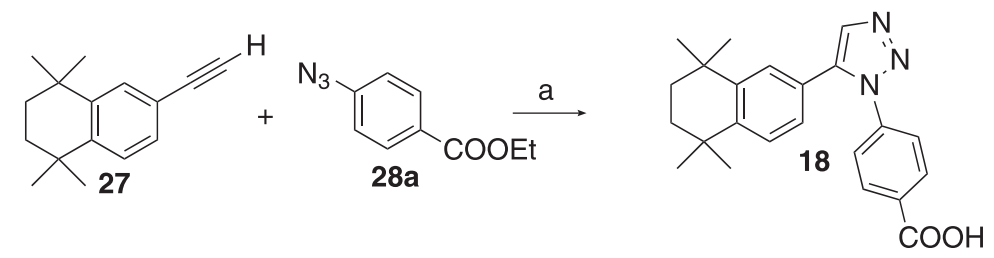

Scheme 6. Synthesis of $\mathbf{1 8}$. Reagents and conditions: (a) $t$-BuOK, DMSO, $96 \mathrm{~h}, 40{ }^{\circ} \mathrm{C}, 75 \%$.

Table 1. Structures and antiproliferative activities of the 1,2,3-triazole retinoid analogs 7-18

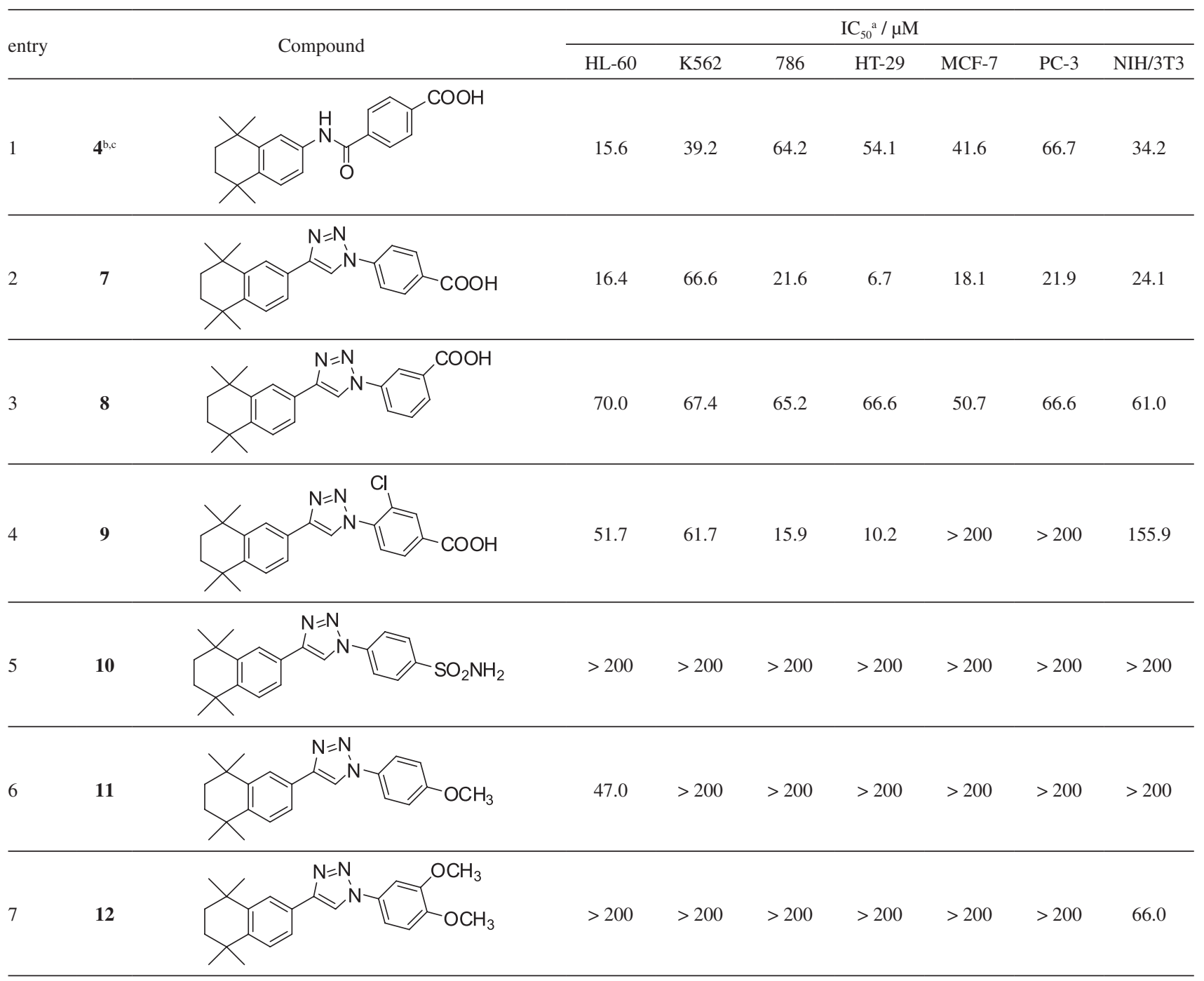


Table 1. Structures and antiproliferative activities of the 1,2,3-triazole retinoid analogs 7-18 (cont.)

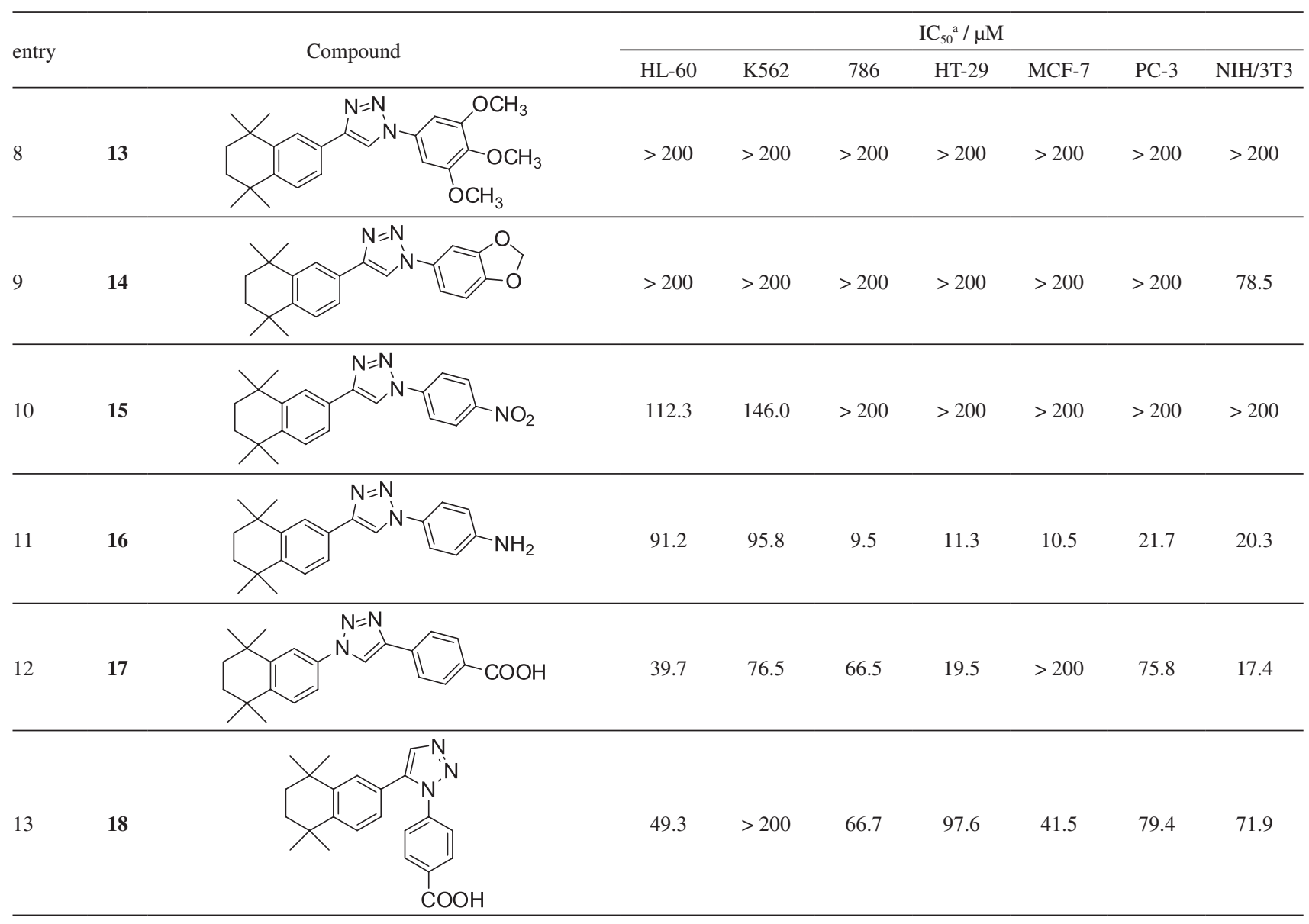

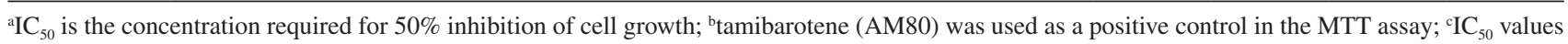
for tamibarotene $(16.1 \mu \mathrm{M})$ are reported in reference 26 .

adenocarcinoma cells (HT-29), breast adenocarcinoma cells (MCF-7), and prostatic adenocarcinoma cells (PC-3). ${ }^{30}$

Thus, this study aims to determine whether retinoids

7-18, containing the 1,2,3-triazole ring, also have a good anticancer activity profile against the solid tumor cells 786, HT-29, MCF-7 and PC-3, since recent studies have shown the potential of tamibarotene analogues against various cancers other than APL. ${ }^{31}$

The assays performed herein show that tamibarotene (AM80) 4 (Table 1, entry 1) has a better anticancer activity profile against the HL60 leukemic cells $(15.6 \mu \mathrm{M})^{31}$ than on the K562 leukemic cells (39.2 $\mu \mathrm{M})$, and moderate activity on solid tumor cells $786(64.2 \mu \mathrm{M})$, HT-29 $(54.1 \mu \mathrm{M})$, MCF-7 $(41.6 \mu \mathrm{M})$ and PC-3 $(66.7 \mu \mathrm{M})$.

1,2,3-Triazolic compound 7 containing a carboxylic acid group at the para position exhibited good antiproliferative activity against HL60 (16.4 $\mu \mathrm{M})$, weak against K562 $(66.6 \mu \mathrm{M})$, very good against HT-29 $(6.7 \mu \mathrm{M})$, and good against MCF-7 $(18 \mu \mathrm{M})$ and PC3 $(21.9 \mu \mathrm{M})$ (Table 1, entry 2$)$.

However, triazole $\mathbf{8}$, with a carboxylic acid at the meta position, showed lower anti-cancer activity compared to triazole 7 (carboxylic acid in the para position), ranging from 50.7 to $70 \mu \mathrm{M}$ for all cell lines tested (Table 1, entry 3 ).

The chloro triazole 9 (Table 1, entry 4) had moderate activity against HL60 and K562 (51.7 and $61.7 \mu \mathrm{M})$, good activity against 786 and HT-29 (15.9 and $10.2 \mu \mathrm{M})$ and no activity against MCF-7 and PC 3 cells. Compounds with chloro at the 3-position, such as UVI2007 6, are known to interact with the RAR $\beta$ receptor selectively, with decreased binding affinity to the RAR $\alpha$ receptor. ${ }^{10}$ The chloro introduction in $\mathbf{7}$ selectively increased its anticancer activity for the 786 and HT-29 cells.

Compound 10, containing an $\mathrm{SO}_{2} \mathrm{NH}_{2}$ group at the para position, which can be considered a bioisosteric substitute for carboxylic acid, ${ }^{32}$ had poor activity against all cancer cell lines tested (Table 1, entry 5).

This aligns with previous results, which demonstrated that classic bioisosteric replacement of a carboxylic acid with a sulfonamide group does not work well for retinoid compounds with anticancer activities against APL. ${ }^{33}$ 
Interestingly, in another study with retinoid-containing bioisosteric exchange groups, compounds having the $-\mathrm{SO}_{2} \mathrm{NH}_{2}$ group had good activity against ovarian cancer. ${ }^{34}$

Compound 11 (Table 1, entry 6), which contains a methoxy group at the para position, similarly to $\mathbf{7}$, had moderate activity against HL 60 cells $(47.0 \mu \mathrm{M})$ and no activity against K562, 786 HT-29, MCF-7 and PC-3 cells. Compounds 12-14 (Table 1, entries 7-9), containing dimethoxy, trimethoxy and methylenedioxy groups, had no activity $(>200 \mu \mathrm{M})$ for all cell lines tested. The introduction of the extra methoxy groups in the meta position can explain these results.

Compound 15 (Table 1, entry 10), containing an electron-withdrawing nitro group at the para position, had weak activity against HL 60 cells $(112.3 \mu \mathrm{M})$, even less activity against $\mathrm{K} 562(146 \mu \mathrm{M})$, and no activity against 786, HT-29, MCF-7, and PC-3 cells.

Compound 16 (Table 1, entry 11), containing an $\mathrm{NH}_{2}$ group at the para position, had weak activity against HL60 $(91.2 \mu \mathrm{M})$ and K562 cells $(95.8 \mu \mathrm{M})$; very good activity against the solid tumor cells $786(9.5 \mu \mathrm{M})$, HT-29 $(11.3 \mu \mathrm{M})$, and MCF-7 (10.5 $\mu \mathrm{M})$; and good activity against PC-3 $(21.7 \mu \mathrm{M})$ cells, which indicates that the $\mathrm{NH}_{2}$ group is a good substituent for solid tumor cancer cells.

Triazole 17 (Table 1, entry 12), a positional isomer of compound 7, showed moderate antiproliferative activity against HL60 $(39.6 \mu \mathrm{M})$, weak activity with $\mathrm{K} 562(76.6 \mu \mathrm{M})$ and $786(66.5 \mu \mathrm{M})$ cells, good activity with HT-29 cells $(19.5 \mu \mathrm{M})$, no activity against MCF-7 $(>200 \mu \mathrm{M})$ and weak activity for PC-3 $(75.8 \mu \mathrm{M})$.

The 1,5-diaryl retinoid derivative $\mathbf{1 8}$ (Table 1, entry 13) showed moderate to weak biological anti-cancer activity against HL60 (49.3 $\mu \mathrm{M}), 786(66.7 \mu \mathrm{M}), \mathrm{HT}-29(97.6 \mu \mathrm{M})$, MCF-7 $(41.5 \mu \mathrm{M})$ and PC-3 $(79.4 \mu \mathrm{M})$ cells and no activity against K562 cells (> $200 \mu \mathrm{M})$.

In relation to selectivity index (SI), tamibarotene showed $\mathrm{SI}=2.2$ for HL60 cells (Table 2, entry 1). Compound 7 showed good SI $=3.6$ for HT-29 cells (Table 2, entry 2) and 16 showed SI = 2.2, 1.8, and 1.9 for 786, HT-29 and MCF-7, respectively (Table 2, entry 4). Compound 9 showed the lowest cytotoxicity (Table 1, entry 3), with SI $=9.8$ and 15.2 for 786 and HT-29 cells, respectively.

\section{Conclusions}

In summary, 12 novel 1,2,3-triazole retinoid 7-18 derivatives of tamibarotene (AM80) 4 were synthesized and evaluated for in vitro anti-cancer activity.

Among the compounds synthesized, triazole 7 stands out, because it is equipotent to tamibarotene $\mathbf{4}$ in relation to the anticancer activity against HL60 cells (Table 1, entries 1-2). With respect to solid tumor cells, triazole 7 is more active for all cancer cells tested when compared to tamibarotene 4 , with prominent anticancer activity for the HT-29 colorectal adenocarcinoma cell line $(6.7 \mu \mathrm{M})$ and with good selectivity index ( $\mathrm{SI}=3.6$ ). Compound $\mathbf{9}$ showed the lowest cytotoxicity among compounds synthesized.

Compound 16, an aminoretinoid triazole containing an $\mathrm{NH}_{2}$ group at the para position, had good anticancer activity against all solid tumor cells tested. $\mathbf{1 6}$ is the most potent anti-cancer compound for breast cancer (MCF-7 cells) of this work, and new studies are being conducted to obtain new analogues of $\mathbf{1 6}$ aiming to obtain more potent compounds and with less cytotoxicity.

Positional isomer $\mathbf{1 7}$ had lower potency than triazole 7, indicating that obtaining a positional isomer of 1,4-diaryl1,2,3-triazole compounds is a critical factor in studies about biological anti-cancer activities.

\section{Experimental}

\section{General remarks}

All solvents were distilled before use according to the standard procedure. All reactions were performed under an atmosphere of dry nitrogen and monitored by thin layer chromatography (TLC) using prepared plates (silica gel 60 F254 on aluminum). The chromatograms were examined under both 254 and $360 \mathrm{~nm}$ UV light or with the developing agent ethanolic vanillin and heat. Flash column chromatography was performed on silica gel 60 (particle size 200-400 mesh ASTM, purchased from Aldrich, USA) and eluted with hexane or hexane/ethyl acetate in different ratios. Melting points were determined using Fisatom 430D equipment. Infrared (IR) spectra were recorded on a Nicolet

Table 2. Selectivity index (SI) ${ }^{a}$ for most active retinoids analogues

\begin{tabular}{|c|c|c|c|c|c|c|c|}
\hline \multirow{2}{*}{ entry } & \multirow{2}{*}{ Compound } & \multicolumn{6}{|c|}{ Selectivity index } \\
\hline & & NIH/3T3 vs. HL60 & NIH/3T3 vs. K562 & NIH/3T3 vs. 786 & NIH/3T3 vs. HT29 & NIH/3T3 vs. MCF-7 & NIH/3T3 vs. PC-3 \\
\hline 1 & $4^{\mathrm{b}}$ & 2.2 & $\mathrm{NC}^{\mathrm{c}}$ & $\mathrm{NC}^{\mathrm{c}}$ & $\mathrm{NC}^{\mathrm{c}}$ & $\mathrm{NC}^{\mathrm{c}}$ & $\mathrm{NC}^{\mathrm{c}}$ \\
\hline 2 & 7 & 1.5 & $\mathrm{NC}^{\mathrm{c}}$ & 1.1 & 3.6 & 1.3 & 1.1 \\
\hline 3 & 9 & $\mathrm{NC}^{\mathrm{c}}$ & $\mathrm{NC}^{\mathrm{c}}$ & 9.8 & 15.2 & $\mathrm{NC}^{\mathrm{c}}$ & $\mathrm{NC}^{\mathrm{c}}$ \\
\hline 4 & 16 & $\mathrm{NC}^{\mathrm{c}}$ & $\mathrm{NC}^{\mathrm{c}}$ & 2.2 & 1.8 & 1.9 & $\mathrm{NC}^{\mathrm{c}}$ \\
\hline
\end{tabular}

${ }^{a} \mathrm{SI}$, selectivity index: $\mathrm{IC}_{50}$ on normal cells / $\mathrm{IC}_{50}$ on cancer cells; ${ }^{\mathrm{b}}$ positive control: tamibarotene for fibroblast cells (NIH/3T3); ${ }^{\mathrm{N}} \mathrm{NC}$ : not calculated. 
iS5 spectrometer from Thermo Scientific. The ${ }^{1} \mathrm{H}$ and ${ }^{13} \mathrm{C}$ nuclear magnetic resonance (NMR) spectra were recorded in $\mathrm{CDCl}_{3}$ solutions using a Bruker $75 \mathrm{MHz}$ or $300 \mathrm{MHz}$ spectrometer, as noted. Chemical shifts $(\delta)$ are expressed as parts per million ( $\mathrm{ppm}$ ) downfield from tetramethylsilane as the internal standard. HR-ESI-MS (high resolution electrospray ionization mass spectrometry) measurements were carried out on a quadrupole time-of-flight instrument (UltrOTOF-Q, Bruker Daltonics, Billerica, MA).

Procedure for the preparation of 2,5-dichloro-2,5-dimethyl hexane $(\mathbf{2 0})^{35}$

A solution of 2,5-dimethyl-2,5-hexanediol 19 $(2.0 \mathrm{mmol})$ in $37 \%$ hydrochloric acid $(42 \mathrm{mmol})$ was stirred at room temperature for $65 \mathrm{~h}$. The mixture was extracted with ethyl acetate and the organic phase was washed with $5 \% \mathrm{NaHCO}_{3}$ and dried over anhydrous $\mathrm{MgSO}_{4}$. The solvent was removed under reduced pressure. The product was purified by flash chromatography and recrystallization using hexane as solvent, which furnished 2,5-dichloro2,5-dimethyl hexane $\mathbf{2 0}$ as white crystals in $85 \%$ yield. mp $68{ }^{\circ} \mathrm{C} ;{ }^{1} \mathrm{H}$ NMR $\left(300 \mathrm{MHz}, \mathrm{CDCl}_{3}\right) \delta 1.58(\mathrm{~s}, 12 \mathrm{H}$, $\left.3 \mathrm{CH}_{3}\right), 1.93\left(\mathrm{~s}, 4 \mathrm{H}, 2 \mathrm{CH}_{2}\right) ;{ }^{13} \mathrm{C} \mathrm{NMR}\left(75 \mathrm{MHz}, \mathrm{CDCl}_{3}\right)$ $\delta 32.52,41.14,70.35$.

Procedure for the preparation of 1,1,4,4-tetramethyl1,2,3,4-tetrahydronaphthalene $(\mathbf{2 2})^{36}$

To a solution of 2,5-dichloro-2,5-dimethyl hexane $\mathbf{2 0}$ $(2.0 \mathrm{mmol})$ in benzene $21\left(2 \mathrm{~mL} \mathrm{mmol}^{-1}\right), \mathrm{AlCl}_{3}(0.2 \mathrm{mmol})$ was added and the reaction mixture was stirred under reflux in nitrogen atmosphere for $64 \mathrm{~h}$. Excess benzene 21 was distilled off and the resulting mixture was poured into distilled water. The mixture was extracted with ethyl acetate and the organic phase was dried over $\mathrm{MgSO}_{4}$. The solvent was removed under vacuum. The residue was purified by distillation at low pressure $(0.5 \mathrm{~mm} \mathrm{Hg})$, and the product 22 was collected between 90 and $120^{\circ} \mathrm{C}$ as a colorless oil in $82 \%$ yield. ${ }^{1} \mathrm{H}$ NMR $\left(300 \mathrm{MHz}, \mathrm{CDCl}_{3}\right) \delta 1.30(\mathrm{~s}, 12 \mathrm{H}$, $\left.3 \mathrm{CH}_{3}\right), 1.71\left(\mathrm{~s}, 4 \mathrm{H}, 2 \mathrm{CH}_{2}\right), 7.15(\mathrm{~m}, 2 \mathrm{H}, \mathrm{Ar}-\mathrm{H}), 7.33(\mathrm{~m}$, $2 \mathrm{H}, \mathrm{Ar}-\mathrm{H}) ;{ }^{13} \mathrm{C} \mathrm{NMR}\left(75 \mathrm{MHz}, \mathrm{CDCl}_{3}\right) \delta 31.88,34.19$, $35.10,125.52,126.45,144.74$.

Procedure for the preparation of 6-bromo-1,1,4,4-tetramethyl-1,2,3,4-tetrahydronaphthalene (23)

To a solution of tetrahydronaphthalene $\mathbf{2 2}(20.0 \mathrm{mmol})$ in $\mathrm{MeOH}\left(2.5 \mathrm{~mL} \mathrm{mmol}^{-1}\right)$, under nitrogen atmosphere, NBS $(1.5 \mathrm{mmol})$ and $\mathrm{TsOH}(0.15 \mathrm{mmol})$ were added. The reaction mixture was refluxed at $55{ }^{\circ} \mathrm{C}$ for $48 \mathrm{~h}$, then poured into saturated $\mathrm{NaHCO}_{3}$ solution and extracted with ethyl acetate $(3 \times 30 \mathrm{~mL})$. The organic phase was dried over $\mathrm{MgSO}_{4}$ and the solvent removed under vacuum. The product was purified by distillation at low pressure $(0.5 \mathrm{~mm} \mathrm{Hg})$ at temperatures between 90 and $145{ }^{\circ} \mathrm{C}$. The product $\mathbf{2 3}$ was obtained as colorless oil in $79 \%$ yield. ${ }^{1} \mathrm{H}$ NMR $\left(300 \mathrm{MHz}, \mathrm{CDCl}_{3}\right)^{37}$ $\delta 1.25\left(\mathrm{~s}, 6 \mathrm{H}, 2 \mathrm{CH}_{3}\right), 1.26\left(\mathrm{~s}, 6 \mathrm{H}, 2 \mathrm{CH}_{3}\right), 1.66\left(\mathrm{~s}, 4 \mathrm{H}, 2 \mathrm{CH}_{2}\right)$, 7.16 (d, 1H, $J 8.5 \mathrm{~Hz}$, Ar-H), 7.23 (dd, 1H, $J 8.5,2.1 \mathrm{~Hz}$, Ar-H), 7.40 (d, 1H, $J 2.1 \mathrm{~Hz}, \mathrm{Ar}-\mathrm{H}) ;{ }^{13} \mathrm{C}$ NMR $(75 \mathrm{MHz}$, $\left.\mathrm{CDCl}_{3}\right) \delta 31.72,31.88,34.06,34.46,34.83,34.86,119.40$, $128.44,128.65,129.42,143.82,147.36$.

General procedure for the preparation of acetylene alcohols 25 and 34

To a solution of the bromines $\mathbf{2 3}$ or $\mathbf{3 3}(3.0 \mathrm{mmol})$ in triethylamine $\left(4.5 \mathrm{~mL} \mathrm{mmol}^{-1}\right)$, under nitrogen atmosphere, $\mathrm{PdCl}_{2}\left(\mathrm{PPh}_{3}\right)_{2}(0.075 \mathrm{mmol}), \mathrm{CuI}(0.15 \mathrm{mmol})$ and 2-methyl3-butyn-2-ol 24 (11.0 mmol) were added. The reaction mixture was stirred under reflux at $75{ }^{\circ} \mathrm{C}$ for $20 \mathrm{~h}$. The excess triethylamine was removed by distillation, and the reaction was extracted with ethyl acetate, dried over $\mathrm{MgSO}_{4}$ and the solvent removed under vacuum.

2-Methyl-4-(5,5,8,8-tetramethyl-5, 6, 7, 8-tetrahydronaphthalen-2-yl)-but-3-yn-2-ol (25) ${ }^{22}$

The product was purified by flash chromatography (hexane/ethyl acetate 99:1) to give $\mathbf{2 5}$ as a yellow crystal in $81 \%$ yield. mp $95{ }^{\circ} \mathrm{C} ;{ }^{1} \mathrm{H}$ NMR $\left(300 \mathrm{MHz}, \mathrm{CDCl}_{3}\right) \delta 1.23$ $\left(\mathrm{s}, 6 \mathrm{H}, 2 \mathrm{CH}_{3}\right), 1.25\left(\mathrm{~s}, 6 \mathrm{H}, 2 \mathrm{CH}_{3}\right), 1.60\left(\mathrm{~s}, 6 \mathrm{H}, 2 \mathrm{CH}_{3}\right), 1.65$ $\left(\mathrm{s}, 4 \mathrm{H}, 2 \mathrm{CH}_{2}\right), 1.98(\mathrm{~s}, 1 \mathrm{H}, \mathrm{OH}), 7.14(\mathrm{dd}, 1 \mathrm{H}, J 8.1,1.6 \mathrm{~Hz}$, Ar-H), 7.21 (d, $1 \mathrm{H}, J 8.1 \mathrm{~Hz}, \mathrm{Ar}-\mathrm{H}), 7.34(\mathrm{~d}, 1 \mathrm{H}, J 1.6 \mathrm{~Hz}$, Ar-H); ${ }^{13} \mathrm{C}$ NMR (75 MHz, $\left.\mathrm{CDCl}_{3}\right) \delta 31.56,31.67,31.72$, $34.15,34.26,34.85,34.92,65.66,82.56,92.54,119.56$, $126.54,128.66,129.89,145.41$.

Ethyl 4-(3-hydroxy-3-methylbut-1-yn-1-yl) benzoate (34) ${ }^{38}$

The product was purified by flash chromatography on silica gel using hexane as eluent, to give $\mathbf{3 4}$ as a yellow oil in $70 \%$ yield. ${ }^{1} \mathrm{H}$ NMR $\left(300 \mathrm{MHz}, \mathrm{CDCl}_{3}\right) \delta 1.35(\mathrm{t}, 3 \mathrm{H}$, $\left.J 7.2 \mathrm{~Hz}, \mathrm{CH}_{3}\right), 1.60\left(\mathrm{~s}, 6 \mathrm{H}, 2 \mathrm{CH}_{3}\right), 2.41(\mathrm{~s}, 1 \mathrm{H}, \mathrm{OH}), 4.34$ (q, 2H, J 7.2 Hz, $\left.\mathrm{CH}_{2}\right), 7.42$ (d, 2H, J 9 Hz, Ar-H), 7.94 (d, $2 \mathrm{H}, J 9 \mathrm{~Hz}, \mathrm{Ar}-\mathrm{H}) ;{ }^{13} \mathrm{C} \mathrm{NMR}\left(75 \mathrm{MHz}, \mathrm{CDCl}_{3}\right) \delta 14.23$, $31.31,61.12,65.52,81.39,96.70,127.35,129.33,129.81$, $131.46,166.06$.

General procedure for the preparation of 6-ethynyl1,1,4,4-tetramethyl-1,2,3,4-tetrahydronaphthalene $\mathbf{2 6}^{38,39}$

To a solution of acetylene alcohol $25(3.0 \mathrm{mmol})$ in toluene $\left(9.0 \mathrm{~mL} \mathrm{mmol}^{-1}\right)$ under nitrogen atmosphere, $\mathrm{KOH}$ 
(9.0 $\mathrm{mmol})$ was added. The reaction mixture was refluxed at $110{ }^{\circ} \mathrm{C}$ for $20 \mathrm{~h}$ and excess toluene was removed by distillation. The residue was extracted with ethyl acetate and the organic phase was dried over $\mathrm{MgSO}_{4}$. The solvent was removed under vacuum. The product was purified by flash chromatography on silica gel using hexane as eluent. The product $\mathbf{2 5}$ was obtained as a yellow oil in $70 \%$ yield. ${ }^{1} \mathrm{H}$ NMR (300 MHz, $\left.\mathrm{CDCl}_{3}\right) \delta 1.25\left(\mathrm{sl}, 12 \mathrm{H}, 4 \mathrm{CH}_{3}\right), 1.66$ (s, 4H, 2 $\mathrm{CH}_{2}$ ), 2.99 (s, 1H, CH), 7.23 (m, 2H, Ar-H), 7.43 (sl, 1H, Ar-H); ${ }^{13} \mathrm{C}$ NMR (75 MHz, $\left.\mathrm{CDCl}_{3}\right) \delta 31.6,31.7$, 34.1, 34.3, 34.8, 34.9, 75.9, 84.2, 119.0, 126.6, 129.1, $130.5,145.0,146.0$.

Procedure for the preparation of ethyl 4-ethynylbenzoate $(35)^{40}$

To a solution of ethyl 4-(3-hydroxy-3-methylbut-1-yn1 -yl) benzoate $34(1.0 \mathrm{mmol})$ in hexane $\left(12 \mathrm{~mL} \mathrm{mmol}^{-1}\right)$, $\mathrm{NaH}(1.8 \mathrm{mmol})$ was added. The reaction mixture was refluxed under nitrogen atmosphere for $48 \mathrm{~h}$. The reaction was extracted with ethyl acetate and the organic phase was dried over $\mathrm{MgSO}_{4}$. The solvent was removed under vacuum. The product was purified by flash chromatography on silica gel using hexane as eluent. The product 35 was obtained as a yellow oil in $65 \%$ yield. ${ }^{1} \mathrm{H} \mathrm{NMR}\left(300 \mathrm{MHz}, \mathrm{CDCl}_{3}\right)$ $\delta 1.37\left(\mathrm{t}, 3 \mathrm{H}, J 6 \mathrm{~Hz}, \mathrm{CH}_{3}\right), 3.20(\mathrm{~s}, 1 \mathrm{H}, \mathrm{CH}), 4.35$ (q, 2H, $\left.J 6 \mathrm{~Hz}, \mathrm{CH}_{2}\right), 7.52$ (d, 2H, J $\left.9 \mathrm{~Hz}, \mathrm{Ar}-\mathrm{H}\right), 7.97$ (d, 2H, $J 9 \mathrm{~Hz}, \mathrm{Ar}-\mathrm{H}) ;{ }^{13} \mathrm{C} \mathrm{NMR}\left(75 \mathrm{MHz}, \mathrm{CDCl}_{3}\right) \delta 14.27,61.18$, 79.93, 82.83, 126.59, 129.40, 130.48, 132.01, 165.91 .

Procedure for the preparation of ethyl 4-amino3-chlorobenzoate $(\mathbf{2 7 c})^{41}$

To a solution of ethyl 4-aminobenzoate $(2.0 \mathrm{mmol})$ in acetonitrile $\left(2 \mathrm{~mL} \mathrm{mmol}^{-1}\right)$, NCS $(2.05 \mathrm{mmol})$ was added. The mixture was refluxed for $5 \mathrm{~h}$. Extraction was performed with ethyl acetate and the organic layer was washed with 5\% $\mathrm{NaOH}$, dried over anhydrous $\mathrm{MgSO}_{4}$, and the solvent was removed under reduced pressure. The product was purified by crystallization in hexane, which furnished 4-amino3-chlorobenzoate 27c as a purple crystal (mp 81-83 ${ }^{\circ} \mathrm{C}$ ) in $86 \%$ yield. ${ }^{1} \mathrm{H}$ NMR $\left(300 \mathrm{MHz}, \mathrm{CDCl}_{3}\right) \delta 1.33(\mathrm{t}, 3 \mathrm{H}$, J 7.0 Hz, $\mathrm{CH}_{3}$ ), 4.29 (q, 2H, J 7.0 Hz, $\mathrm{CH}_{2}$ ), 6.70 (d, 1H, $J 8.5 \mathrm{~Hz}, \mathrm{Ar}-\mathrm{H}), 7.72(\mathrm{dd}, 1 \mathrm{H}, J 8.4,1.9 \mathrm{~Hz}, \mathrm{Ar}-\mathrm{H}), 7.92(\mathrm{~d}, 1 \mathrm{H}$, $J 1.9 \mathrm{~Hz}, \mathrm{Ar}-\mathrm{H}) ;{ }^{13} \mathrm{C} \mathrm{NMR}\left(75 \mathrm{MHz}, \mathrm{CDCl}_{3}\right) \delta 14.30,60.62$, $114.35,118.06,120.63,129.52$, 131.12, 146.97, 165.74.

Procedure for the preparation of 1,1,4,4-tetramethyl-6-nitro1,2,3,4-tetrahydronaphthalene $(\mathbf{3 0})^{42}$

To a solution of tetrahydronaphthalene $22(10 \mathrm{mmol})$ in acetic anhydride $\left(1 \mathrm{~mL} \mathrm{mmol}{ }^{-1}\right)$, under nitrogen atmosphere, at $0{ }^{\circ} \mathrm{C}$, a solution of $\mathrm{HNO}_{3}(0.05 \mathrm{M})$ in $1 \mathrm{~mL}$ of acetic anhydride was added dropwise. The mixture was stirred at room temperature for $2 \mathrm{~h}$ and then extracted with ether. The organic phase was washed with a saturated solution of $\mathrm{Na}_{2} \mathrm{CO}_{3}$, and dried over anhydrous $\mathrm{MgSO}_{4}$. The solvent was removed under vacuum and the product was purified by flash chromatography on silica gel using hexane as eluent. The product $\mathbf{3 0}$ was obtained as a yellow oil in $92 \%$ yield. ${ }^{1} \mathrm{H}$ NMR $\left(300 \mathrm{MHz}, \mathrm{CDCl}_{3}\right) \delta 1.29(\mathrm{~s}$, $\left.6 \mathrm{H}, 2 \mathrm{CH}_{3}\right), 1.31$ (s, 6H, 2CH $\mathrm{CH}_{3}, 1.71\left(\mathrm{~s}, 4 \mathrm{H}, \mathrm{CH}_{2}\right), 7.42$ (d, 1H, J 8.7 Hz, Ar-H), 7.92 (dd, 1H, J 8.7, $2.4 \mathrm{~Hz}$, Ar-H), 8.16 (d, 1H, J 2.4 Hz, Ar-H); ${ }^{13} \mathrm{C}$ NMR (75 MHz, $\mathrm{CDCl}_{3}$ ) $\delta 31.51,31.63,34.48,34.60,34.71,120.42,121.84,127.67$, $144.71,146.71,152.73$.

Procedure for the preparation of 5,5,8,8-tetramethyl5,6,7,8-tetrahydronaphthalen-2-amine $(\mathbf{3 1})^{42}$

To a solution of nitro-1,2,3,4-tetrahydronaphthalenes $\mathbf{3 0}$ $(5.0 \mathrm{mmol})$ in $95 \%$ ethanol $\left(35 \mathrm{~mL} \mathrm{mmol}^{-1}\right)$, powdered iron (150 mmol) and $\mathrm{CaCl}_{2}(50 \mathrm{mmol})$ were added. The mixture was refluxed at $78{ }^{\circ} \mathrm{C}$ for $48 \mathrm{~h}$. The reaction mixture was extracted with ethyl acetate and the organic phase dried over anhydrous $\mathrm{MgSO}_{4}$. The solvent was then removed under vacuum. The product was purified by flash chromatography using hexane/ethyl acetate 90:10 as eluent. The product 31 was obtained as a brown crystal in $75 \%$ yield. mp $71^{\circ} \mathrm{C}$; ${ }^{1} \mathrm{H} \mathrm{NMR}\left(300 \mathrm{MHz} \mathrm{CDCl}_{3}\right) \delta 1.21\left(\mathrm{~s}, 6 \mathrm{H}, 2 \mathrm{CH}_{3}\right), 1.23(\mathrm{~s}$, $6 \mathrm{H}, 2 \mathrm{CH}_{3}$ ), 1.62 (s, 4H, $\mathrm{CH}_{2}$ ), 3.48 (ls, 2H, $\mathrm{NH}_{2}$ ), 6.61 (d, 1H, J 2.7 Hz, Ar-H), 6.50 (dd, 1H, J 8.1, 2.7 Hz, Ar-H), 7.08 (d, 1H, J 8.1 Hz, Ar-H); ${ }^{13} \mathrm{C}$ NMR $\left(75 \mathrm{MHz}, \mathrm{CDCl}_{3}\right.$ ) $\delta 31.80,32.00,33.53,34.20,35.23,112.88,113.62$, 127.37, $135.38,143.58,145.82$.

General procedure for the preparation of the azides $\mathbf{2 8 a - i}$ and $32^{23}$

To a solution of amine $\mathbf{2 7 a} \mathbf{a}$ i and $\mathbf{3 1}(2.0 \mathrm{mmol})$ in acetonitrile $\left(3.8 \mathrm{~mL} \mathrm{mmol}^{-1}\right), t$-BuONO $(4.3 \mathrm{mmol})$ and $\mathrm{TMSN}_{3}(3.26 \mathrm{mmol})$ were added dropwise under a nitrogen atmosphere, at $0{ }^{\circ} \mathrm{C}$. The reaction mixture was stirred at room temperature for $2 \mathrm{~h}$. The solution was poured into water, extracted with ethyl acetate and the organic phase was dried over anhydrous $\mathrm{MgSO}_{4}$. The solvent was removed under vacuum.

\section{Ethyl 4-azidobenzoate (28a) ${ }^{43}$}

The compound was used without purification and it was obtained as an orange oil in $96 \%$ yield. ${ }^{1} \mathrm{H}$ NMR $(300 \mathrm{MHz}$, $\left.\mathrm{CDCl}_{3}\right) \delta 1.37\left(\mathrm{t}, 3 \mathrm{H}, J 7.1 \mathrm{~Hz}, \mathrm{CH}_{3}\right), 4.34(\mathrm{q}, 2 \mathrm{H}, J 7.0 \mathrm{~Hz}$, 
$\left.2 \mathrm{CH}_{2}\right), 7.04(\mathrm{~d}, 2 \mathrm{H}, J 8.6 \mathrm{~Hz}, \mathrm{Ar}-\mathrm{H}), 8.02(\mathrm{~d}, 2 \mathrm{H}, J 8.6 \mathrm{~Hz}$, $\mathrm{Ar}-\mathrm{H}) ;{ }^{13} \mathrm{C}$ NMR $\left(75 \mathrm{MHz}, \mathrm{CDCl}_{3}\right) \delta 14.31,61.04,118.76$, 127.01, 131.34, 144.59, 165.81 .

\section{Ethyl 3-azidobenzoate (28b) ${ }^{44}$}

The product was purified by flash chromatography on silica gel using a hexane/ethyl acetate (94:6) solution as the mobile phase, which furnished the product as a yellow oil in $80 \%$ yield. ${ }^{1} \mathrm{H}$ NMR $\left(300 \mathrm{MHz}, \mathrm{CDCl}_{3}\right) \delta 1.38(\mathrm{t}, 3 \mathrm{H}$, $\left.J 6 \mathrm{~Hz}, \mathrm{CH}_{3}\right), 4.36\left(\mathrm{q}, 2 \mathrm{H}, J 6 \mathrm{~Hz}, \mathrm{CH}_{2}\right), 7.18(\mathrm{ddd}, 1 \mathrm{H}$, $J$ 8.0, 2.4, $1.0 \mathrm{~Hz}, \mathrm{Ar}-\mathrm{H}), 7.41$ (dd, J 8.1, 7.7 Hz, Ar-H), 7.69 (dd, 1H, J 2.4, 1.6 Hz, Ar-H), 7.80 (ddd, 1H, J 7.6, 1.3, $1.1 \mathrm{~Hz}, \mathrm{Ar}-\mathrm{H}) ;{ }^{13} \mathrm{C}$ NMR $\left(75 \mathrm{MHz}, \mathrm{CDCl}_{3}\right) \delta 14.38,61.35$, 119.91, 123.28, 125.96, 129.76, 132.24, 140.49, 165.70.

\section{Ethyl 4-azido-2-chlorobenzoate (28c)}

The product was purified by flash chromatography on silica gel using hexane as eluent, which furnished the product as a yellow crystal in $92 \%$ yield. IR $(\mathrm{KBr})$ $\mathrm{v} / \mathrm{cm}^{-1}$ 3257, 3102-2911, 2130, 1716, 1596, 1490, 1405, 1311-1286, 1247, 759; ${ }^{1} \mathrm{H}$ NMR (300 MHz, $\left.\mathrm{CDCl}_{3}\right) \delta 1.37$ (t, 3H, J 7.1 Hz, $\mathrm{CH}_{3}$ ), 4.35 (q, 2H, J 7.1 Hz, $\left.\mathrm{CH}_{2}\right), 7.20$ (d, $1 \mathrm{H}, J 8.4 \mathrm{~Hz}, \mathrm{Ar}-\mathrm{H}), 7.94$ (dd, 1H, J 8.4, $1.8 \mathrm{~Hz}, \mathrm{Ar}-\mathrm{H}$ ), $8.03(\mathrm{~d}, 1 \mathrm{H}, J 1.8 \mathrm{~Hz}, \mathrm{Ar}-\mathrm{H}) ;{ }^{13} \mathrm{C}$ NMR $\left(75 \mathrm{MHz}, \mathrm{CDCl}_{3}\right)$ $\delta 14.28,61.45,119.23,124.87,127.92,129.17,132.00$, 141.62, 164.78. HRMS (ESI+) $\mathrm{m} / z$ calcd. for $\mathrm{C}_{9} \mathrm{H}_{8} \mathrm{ClN}_{3} \mathrm{O}_{2}$ $[\mathrm{M}+\mathrm{H}]^{+}:$:226.0383; found: 226.0394 .

\section{4-Azidobenzenesulfonamide (28d $)^{45}$}

The product was purified by flash chromatography on silica gel using a hexane/ethyl acetate (60:40) solution as eluent, which furnished the product as white crystals in $50 \%$ yield. ${ }^{1} \mathrm{H}$ NMR $\left(300 \mathrm{MHz}, \mathrm{DMSO}-d_{6}\right) \delta 6.43(\mathrm{sl}, 2 \mathrm{H}$, $\mathrm{NH}_{2}$ ), 6.90 (dd, $J$ 8.7, $0.5 \mathrm{~Hz}, \mathrm{Ar}-\mathrm{H}$ ), 7.70 (dd, 2H, $J$ 8.7, $0.5 \mathrm{~Hz}, \mathrm{Ar}-\mathrm{H}) ;{ }^{13} \mathrm{C}$ NMR $\left(75 \mathrm{MHz}, \mathrm{DMSO}-d_{6}\right) \delta 119.52$, 127.66, 140.52, 142.98 .

\section{1-Azido-4-methoxybenzene (28e $)^{46}$}

The product was purified by flash chromatography on silica gel using a hexane/ethyl acetate (95:5) solution as the mobile phase, which furnished the product as yellow crystals in $73 \%$ yield. ${ }^{1} \mathrm{H}$ NMR $\left(300 \mathrm{MHz}, \mathrm{CDCl}_{3}\right) \delta 3.78$ $\left(\mathrm{s}, 3 \mathrm{H}, \mathrm{OCH}_{3}\right), 6.87(\mathrm{~d}, 2 \mathrm{H}, J 9.0 \mathrm{~Hz}, \mathrm{Ar}-\mathrm{H}), 6.94(\mathrm{~d}, 2 \mathrm{H}$, $J 8.9 \mathrm{~Hz}, \mathrm{Ar}-\mathrm{H}) ;{ }^{13} \mathrm{C}$ NMR $\left(75 \mathrm{MHz}, \mathrm{CDCl}_{3}\right) \delta 55.49$, 115.05, 119.93, 132.26, 156.93.

\section{4-Azido-1,2-dimethoxybenzene (28f) ${ }^{46}$}

The product was purified by flash chromatography on silica gel using a hexane/ethyl acetate (70:30) solution as the mobile phase, which furnished the product as yellow crystals in $78 \%$ yield. ${ }^{1} \mathrm{H}$ NMR $\left(300 \mathrm{MHz}, \mathrm{CDCl}_{3}\right) \delta 3.84$ (s, $\left.6 \mathrm{H}, 2 \mathrm{OCH}_{3}\right), 6.49\left(\mathrm{~d}, 1 \mathrm{H}, J 2.5 \mathrm{~Hz}, \mathrm{CH}_{2}\right), 6.58(\mathrm{dd}, 1 \mathrm{H}$, $J$ 8.4, $2.4 \mathrm{~Hz}, \mathrm{Ar}-\mathrm{H}), 6.81$ (d, 1H, J 8.6 Hz, Ar-H); ${ }^{13} \mathrm{C}$ NMR $\left(75 \mathrm{MHz}, \mathrm{CDCl}_{3}\right) \delta 55.92,56.17,103.15,110.40,112.01$, $132.72,146.48,149.95$.

\section{5-Azido-1,2,3-trimethoxybenzene $\mathbf{( 2 8 g})^{46}$}

The product was purified by flash chromatography on silica gel using a hexane/ethyl acetate (90:10) solution as the mobile phase, which furnished the product as yellow crystals in $87 \%$ yield. ${ }^{1} \mathrm{H}$ NMR ( $\left.300 \mathrm{MHz}, \mathrm{CDCl}_{3}\right) \delta 3.78$ (s, $\left.3 \mathrm{H}, \mathrm{OCH}_{3}\right), 3.82\left(\mathrm{~s}, 6 \mathrm{H}, 2 \mathrm{OCH}_{3}\right), 6.21$ (s, $\left.2 \mathrm{H}, \mathrm{Ar}-\mathrm{H}\right)$; ${ }^{13} \mathrm{C} \mathrm{NMR}\left(75 \mathrm{MHz}, \mathrm{CDCl}_{3}\right) \delta 56.17,61.00,96.40,135.35$, 135.64, 154.07.

\section{5-Azidobenzo-1,3-dioxole (28h) ${ }^{46}$}

The product was purified by flash chromatography on silica gel using hexane as the mobile phase, which furnished the product as a brown oil in $75 \%$ yield. ${ }^{1} \mathrm{H}$ NMR $\left(300 \mathrm{MHz}, \mathrm{CDCl}_{3}\right) \delta 5.95$ (s, 2H, $\mathrm{CH}_{2}$ ), 6.47 (dd, $1 \mathrm{H}, J$ J .2 , $2.3 \mathrm{~Hz}, \mathrm{Ar}-\mathrm{H}), 6.51$ (d, 1H, J 2.1 Hz, Ar-H), $6.75(\mathrm{~d}, 1 \mathrm{H}$, $J 8.3 \mathrm{~Hz}, \mathrm{Ar}-\mathrm{H}) ;{ }^{13} \mathrm{C}$ NMR $\left(75 \mathrm{MHz}, \mathrm{CDCl}_{3}\right) \delta 100.66$, $101.59,108.75,111.58,133.74,145.01,148.64$.

\section{1-Azido-4-nitrobenzene (28i) ${ }^{47}$}

The product was purified by flash chromatography on silica gel using hexane as the mobile phase, which furnished the product as yellow crystals in $79 \%$ yield. ${ }^{1} \mathrm{H}$ NMR $\left(300 \mathrm{MHz}, \mathrm{CDCl}_{3}\right) \delta 7.12$ (d, 2H, J 9.0 Hz, Ar-H), 8.22 (d, $2 \mathrm{H}, J 9.0 \mathrm{~Hz}, \mathrm{Ar}-\mathrm{H}) ;{ }^{13} \mathrm{C} \mathrm{NMR}\left(75 \mathrm{MHz}, \mathrm{CDCl}_{3}\right) \delta 119.39$, 125.61, 144.64, 146.87.

6-Azido-1,1,4,4-tetramethyl-1,2,3,4-tetrahydro-naphthalene (32)

The product was purified by flash chromatography on silica gel using hexane as the mobile phase, which furnished the product as a brown oil in $86 \%$ yield. IR $(\mathrm{KBr}) \mathrm{V} / \mathrm{cm}^{-1}$ 2962-2861, 2111, 1604, 1517, 1496, 1309, 1276, 1139, 811; ${ }^{1} \mathrm{H}$ NMR $\left(300 \mathrm{MHz}, \mathrm{CDCl}_{3}\right) \delta 1.24\left(\mathrm{~s}, 6 \mathrm{H}, 2 \mathrm{CH}_{3}\right), 1.25$ (s, $\left.6 \mathrm{H}, 2 \mathrm{CH}_{3}\right), 1.66\left(\mathrm{~s}, 4 \mathrm{H}, \mathrm{CH}_{3}\right), 6.81(\mathrm{dd}, 1 \mathrm{H}, J 8.4,2.4 \mathrm{~Hz}$, Ar-H), 6.90 (d, 1H, J 2.4 Hz, Ar-H), 7.27 (d, 1H, J 8.4 Hz, Ar-H); ${ }^{13} \mathrm{C} \mathrm{NMR}\left(75 \mathrm{MHz}, \mathrm{CDCl}_{3}\right) \delta 31.74,31.86,34.51$, 34.96, 35.28, 116.46, 116.90, 128.08, 137.01, 141.89, 146.83. HRMS (ESI+) $\mathrm{m} / \mathrm{z}$ calcd. for $\mathrm{C}_{14} \mathrm{H}_{19} \mathrm{~N}_{3}[\mathrm{M}+\mathrm{H}]^{+}$: 230.1657; found: 230.2411 .

General procedure for the preparation of triazole analogues 10-15, 29a-c, 36

To a solution of the azides $(2.2 \mathrm{mmol})$ and terminal acetylenes (2.0 mmol) in $\mathrm{CH}_{2} \mathrm{Cl}_{2} / \mathrm{H}_{2} \mathrm{O}\left(1: 1 ; 4 \mathrm{~mL} \mathrm{mmol}^{-1}\right)$, $\mathrm{CuSO}_{4} .5 \mathrm{H}_{2} \mathrm{O}(0.15 \mathrm{mmol})$ and sodium ascorbate 
(0.35 mmol) were added. The mixture was stirred at room temperature for $48 \mathrm{~h}$ and then extracted with ethyl acetate, the organic phase was dried over anhydrous $\mathrm{MgSO}_{4}$ and the solvent was removed under vacuum.

4-(4-(5,5,8,8-Tetramethyl-5,6,7,8-tetrahydro-naphtha-lene2-yl)-1 H-1,2,3-triazol-1-yl)benzene-sulfonamide (10)

The product $\mathbf{1 0}$ was purified by crystallization in an ethyl acetate/ethanol (70:30) solution and then filtered using Celite. The product was obtained as white crystals in $50 \%$ yield. mp $282^{\circ} \mathrm{C}$; IR (KBr) v / cm $\mathrm{cm}^{-1} 3359,3162$, 3066, 2964-2859, 1598, 1482, 1348, 1159, 844; ${ }^{1} \mathrm{H}$ NMR $\left(300 \mathrm{MHz}, \mathrm{DMSO}-d_{6}\right) \delta 1.27\left(\mathrm{~s}, 6 \mathrm{H}, 2 \mathrm{CH}_{3}\right), 1.32(\mathrm{~s}, 6 \mathrm{H}$, $\left.2 \mathrm{CH}_{3}\right), 1.67$ (s, 4H, CH$)_{2} 7.44$ (d, 1H, J $\left.8.3 \mathrm{~Hz}, \mathrm{Ar}-\mathrm{H}\right)$, 7.55 (s, 2H, Ar-H), 7.69 (dd, 1H, J 8.2, 1.6 Hz, Ar-H), 7.87 (d, 1H, J 1.6 Hz, Ar-H), 8.06 (d, 2H, J 8.8 Hz, Ar-H), 8.18 (d, 2H, J $8.8 \mathrm{~Hz}$, Ar-H), 9.40 (s, 1H, *Tr-H); ${ }^{13} \mathrm{C}$ NMR $\left(75 \mathrm{MHz}, \mathrm{DMSO}-d_{6}\right) \delta 31.58,31.69,34.01,34.10,34.57$, $119.41,120.15,122.85,123.57,127.20,127.64,138.73$, 143.81, 144.91, 145.16, 148.03. HRMS (ESI+) $\mathrm{m} / \mathrm{z}$ calcd. for $\mathrm{C}_{22} \mathrm{H}_{26} \mathrm{~N}_{4} \mathrm{O}_{2} \mathrm{~S}[\mathrm{M}+\mathrm{H}]^{+}$: 411.1854; found: 411.1862 . Calcd. for $\mathrm{C}_{22} \mathrm{H}_{26} \mathrm{~N}_{4} \mathrm{O}_{2} \mathrm{~S}[\mathrm{M}+\mathrm{Na}]^{+}$: 433.1674; found: 433.1679. *Tr: triazole hydrogen.

1-(4-Methoxyphenyl)-4-(5,5,8,8-tetramethyl-5,6,7,8-tetrahydronaphthalene-2-yl)-1H-1,2,3-triazole (11)

The product 11 was purified by flash chromatography on silica gel using a hexane/ethyl acetate (80:20) solution as the mobile phase, which furnished the product as white crystals in $81 \%$ yield. mp $135^{\circ} \mathrm{C}$; IR (KBr) $v / \mathrm{cm}^{-1} 2960-2856,1518$, $1253,1042,832,781 ;{ }^{1} \mathrm{H}$ NMR (300 MHz, DMSO- $\left.d_{6}\right) \delta 1.26$ $\left(\mathrm{s}, 6 \mathrm{H}, 2 \mathrm{CH}_{3}\right), 1.30\left(\mathrm{~s}, 6 \mathrm{H}, 2 \mathrm{CH}_{3}\right), 1.66\left(\mathrm{~s}, 4 \mathrm{H}, 2 \mathrm{CH}_{2}\right), 3.83$ (s, 3H, $\left.\mathrm{OCH}_{3}\right), 7.16(\mathrm{~d}, 2 \mathrm{H}, J 9.0 \mathrm{~Hz}, \mathrm{Ar}-\mathrm{H}), 7.41$ (d, 1H, $J 8.2 \mathrm{~Hz}, \mathrm{Ar}-\mathrm{H}), 7.65$ (d, 1H, J 8.2 Hz, Ar-H), 7.85 (m, 3H, $\mathrm{Ar}-\mathrm{H}), 9.17$ (s, 1H, *Tr-H); ${ }^{13} \mathrm{C}$ NMR (75 MHz, DMSO- $d_{6}$ ) $\delta 31.56,31.66,33.94,34.05,34.62,55.63,114.95,119.20$, $121.60,122.75,123.39,127.04,127.63,130.16,144.51$, 145.00, 147.48, 159.29. HRMS (ESI+) $\mathrm{m} / z$ calcd. for $\mathrm{C}_{23} \mathrm{H}_{27} \mathrm{~N}_{3} \mathrm{O}[\mathrm{M}+\mathrm{H}]^{+}$: 362.2232; found: 262.2246. Calcd. for $\mathrm{C}_{23} \mathrm{H}_{27} \mathrm{~N}_{3} \mathrm{O}[\mathrm{M}+\mathrm{Na}]^{+}$: 384.2052; found: 384.2066. *Tr: triazole hydrogen.

1-(3,4-Dimethoxyphenyl)-4-(5,5,8,8-tetramethyl5,6,7,8-tetrahydronaphtha-lene-2-yl)-1H-1,2,3-triazole (12)

The product 12 was purified by flash chromatography on silica gel using a hexane/ethyl acetate (85:15) solution as eluent, which furnished the product as white crystals in $62 \%$ yield. mp $126^{\circ} \mathrm{C}$; IR (KBr) v / cm ${ }^{-1} 2958-2857,1603$, 1510, 1470, 1232, 1125, 1040, 817; ' $\mathrm{H}$ NMR (300 MHz, DMSO- $\left.d_{6}\right) \delta 1.27\left(\mathrm{~s}, 6 \mathrm{H}, 2 \mathrm{CH}_{3}\right), 1.32\left(\mathrm{~s}, 6 \mathrm{H}, 2 \mathrm{CH}_{3}\right), 1.68$ (s, 4H, 2CH $\mathrm{CH}_{2}, 3.84\left(\mathrm{~s}, 3 \mathrm{H}, \mathrm{OCH}_{3}\right), 3.89\left(\mathrm{~s}, 3 \mathrm{H}, \mathrm{OCH}_{3}\right)$,
7.17 (d, 1H, J 8.6 Hz, Ar-H), 7.47 (m, 3H, Ar-H), 7.67 (dd, 1H, J 8.1, 1.4 Hz, Ar-H), 7.85 (d, 1H, J 1.4 Hz, Ar-H), 9.18 $\left(\mathrm{s}, 1 \mathrm{H},{ }^{*} \mathrm{Tr}-\mathrm{H}\right) ;{ }^{13} \mathrm{C}$ NMR $\left(75 \mathrm{MHz}, \mathrm{DMSO}-d_{6}\right) \delta 31.51$, 31.62, 33.88, 33.99, 34.50, 34.57, 55.83, 55.93, 104.53, $112.05,119.16,122.72,123.26,126.96,127.61,130.14$, 144.43, 144.92, 147.35, 148.87, 149.34. HRMS (ESI+) $m / z$ calcd. for $\mathrm{C}_{24} \mathrm{H}_{29} \mathrm{~N}_{3} \mathrm{O}_{2}[\mathrm{M}+\mathrm{H}]^{+}$: 392.2338; found: 392.2357. Calcd. for $\mathrm{C}_{24} \mathrm{H}_{29} \mathrm{~N}_{3} \mathrm{O}_{2}[\mathrm{M}+\mathrm{Na}]^{+}$: 414.2158; found: 414.2173 . ${ }^{*} \mathrm{Tr}$ : triazole hydrogen.

4-(5,5,8,8-Tetramethyl-5,6,7,8-tetrahydronaphthalene-2-yl)1-(3,4,5-trimethoxyphenyl)-1H-1,2,3-triazole (13)

The product 13 was purified by flash chromatography on silica gel using a hexane/ethyl acetate (85:15) solution as the mobile phase, which furnished the product as white crystals in $84 \%$ yield. $\mathrm{mp} 99^{\circ} \mathrm{C}$; IR (KBr) v / $\mathrm{cm}^{-1} 2959-2857,1604$, 1518, 1261, 1137, 1043, 1027, 797; ${ }^{1} \mathrm{H}$ NMR (300 MHz, DMSO- $\left.d_{6}\right) \delta 1.25\left(\mathrm{~s}, 6 \mathrm{H}, 2 \mathrm{CH}_{3}\right), 1.30\left(\mathrm{~s}, 6 \mathrm{H}, 2 \mathrm{CH}_{3}\right), 1.65(\mathrm{~s}$, $\left.4 \mathrm{H}, 2 \mathrm{CH}_{2}\right), 3.71\left(\mathrm{~s}, 3 \mathrm{H}, \mathrm{OCH}_{3}\right), 3.88\left(\mathrm{~s}, 6 \mathrm{H}, 2 \mathrm{OCH}_{3}\right), 7.23$ (s, 2H, Ar-H), 7.42 (d, 1H, J $8.3 \mathrm{~Hz}, \mathrm{Ar}-\mathrm{H}), 7.65$ (dd, 1H, $J$ 8.3, $1.7 \mathrm{~Hz}, \mathrm{Ar}-\mathrm{H}), 7.83$ (d, 1H, J 1.7 Hz, Ar-H), 9.18 (s, $1 \mathrm{H}, * \mathrm{Tr}-\mathrm{H}) ;{ }^{13} \mathrm{C}$ NMR $\left(75 \mathrm{MHz}, \mathrm{DMSO}-d_{6}\right) \delta 31.68,31.81$, 34.08, 34.18, 34.65, 34.72, 56.52, 60.44, 98.13, 119.49, $122.99,123.44,127.25,127.59,132.73,137.55,144.83$, 145.22, 147.66, 153.73. HRMS (ESI+) $\mathrm{m} / \mathrm{z}$ calcd. for $\mathrm{C}_{25} \mathrm{H}_{31} \mathrm{~N}_{3} \mathrm{O}_{3}[\mathrm{M}+\mathrm{H}]^{+}$: 422.2443; found: 422.2448. Calcd. for $\mathrm{C}_{25} \mathrm{H}_{31} \mathrm{~N}_{3} \mathrm{O}_{3}[\mathrm{M}+\mathrm{Na}]^{+}$: 444.2263; found: 444.2267. *Tr: triazole hydrogen.

1 -(Benzo-1,3-dioxol-5-yl)-4-(5,5,8,8-tetramethyl5,6,7,8-tetrahydronaphtha-lene-2-yl)-1 $\mathrm{H}$-1,2,3-triazole (14)

The product $\mathbf{1 4}$ was purified by crystallization in a hexane/ethyl acetate (70:30) solution. The product was obtained as white crystals in $69 \%$ yield. mp $163{ }^{\circ} \mathrm{C}$; IR (KBr) $v / \mathrm{cm}^{-1}$ 3140, 2957-2857, 1505, 1485, 1248, 1040, 804; ${ }^{1} \mathrm{H}$ NMR $\left(300 \mathrm{MHz}, \mathrm{DMSO}-d_{6}\right) \delta 1.27\left(\mathrm{~s}, 6 \mathrm{H}, 2 \mathrm{CH}_{3}\right)$, 1.31 (s, 6H, $\left.\mathrm{CH}_{3}\right), 1.67$ (s, 4H, 2CH$), 6.16$ (s, 2H, $\left.\mathrm{CH}_{2}\right), 7.13$ (d, 1H,J $8.3 \mathrm{~Hz}$, Ar-H), 7.42 (d, 1H, J $8.3 \mathrm{~Hz}$, Ar-H), 7.43 (dd, 1H, J 8.3, 1.9 Hz, Ar-H), 7.53 (d, 1H, J 2.1 Hz, Ar-H), 7.65 (dd, 1H, J 8.2, 1.7 Hz, Ar-H), 7.83 (d, 1H, J 1.6 Hz, Ar-H), 9.13 (s, 1H, $\left.{ }^{*} \mathrm{Tr}-\mathrm{H}\right) ;{ }^{13} \mathrm{C}$ NMR $\left(75 \mathrm{MHz}, \mathrm{DMSO}-d_{6}\right)$ $\delta 31.55,31.66,33.94,34.05,34.55,34.61,101.84,102.21$, $108.73,113.69,119.41,122.73,123.41,127.06,127.53$, 131.18, 144.58, 145.02, 147.44, 148.27. HRMS (ESI+) $m / z$ calcd. for $\mathrm{C}_{23} \mathrm{H}_{25} \mathrm{~N}_{3} \mathrm{O}_{2}[\mathrm{M}+\mathrm{H}]^{+}:$376.2025; found: 376.2032. Calcd. for $\mathrm{C}_{23} \mathrm{H}_{25} \mathrm{~N}_{3} \mathrm{O}_{2}[\mathrm{M}+\mathrm{Na}]^{+}$: 398.1845; found: 398.1846 . ${ }^{*} \mathrm{Tr}$ : triazole hydrogen.

1-(4-Nitrophenyl)-4-(5,5,8,8-tetramethyl-5,6,7,8-tetrahydronaphthalen-2-yl)-1 $\mathrm{H}$-1,2,3-triazole (15)

The product 15 was purified by flash chromatography 
on silica gel using a hexane/ethyl acetate (90:10) solution as the mobile phase, which furnished the product as yellow crystals in $61 \%$ yield. mp $205^{\circ} \mathrm{C}$; IR $(\mathrm{KBr}) \mathrm{v} / \mathrm{cm}^{-1} 3157$, 3096, 2965-2861, 1596, 1523, 1338, 1231, 1037, 849, 748; ${ }^{1} \mathrm{H}$ NMR $\left(300 \mathrm{MHz}, \mathrm{CDCl}_{3}\right) \delta 1.31\left(\mathrm{~s}, 6 \mathrm{H}, 2 \mathrm{CH}_{3}\right), 1.35$ (s, $\left.6 \mathrm{H}, 2 \mathrm{CH}_{3}\right), 1.71\left(\mathrm{~s}, 4 \mathrm{H}, 2 \mathrm{CH}_{2}\right), 7.40(\mathrm{~d}, 1 \mathrm{H}, J 8.3 \mathrm{~Hz}, \mathrm{Ar}-\mathrm{H})$, 7.61 (dd, $1 \mathrm{H}, J$ 8.2, $1.7 \mathrm{~Hz}, \mathrm{Ar}-\mathrm{H}), 7.87(\mathrm{~d}, 1 \mathrm{H}, J 1.7 \mathrm{~Hz}$, Ar-H), 8.03 (d, 2H, J 9.0 Hz, Ar-H), 8.24 (s, 1H, *Tr-H), 8.42 $(\mathrm{d}, 2 \mathrm{H}, J 9.0 \mathrm{~Hz}, \mathrm{Ar}-\mathrm{H}) ;{ }^{13} \mathrm{C} \mathrm{NMR}\left(75 \mathrm{MHz}, \mathrm{CDCl}_{3}\right) \delta 31.79$, $31.86,34.35,34.43,34.94,35.05,116.72,120.31,123.31$, $124.18,125.54,126.65,127.32,141.26,145.79,146.05$, 147.10, 149.60. HRMS (ESI+) $\mathrm{m} / z$ calcd. for $\mathrm{C}_{22} \mathrm{H}_{24} \mathrm{~N}_{4} \mathrm{O}_{2}$ $[\mathrm{M}+\mathrm{H}]^{+}: 377.1977$; found: $377.1974 . *$ Tr: triazole hydrogen.

Procedure for the preparation of 4-(4-(5,5,8,8-tetramethyl5,6,7,8-tetrahydronaphthalen2-yl)-1 H-1,2,3-triazol-1-yl) aniline (16)

To a solution of 1-(4-nitrophenyl)-4-(5,5,8,8-tetramethyl5,6,7,8-tetrahydronaphthalen-2-yl)- $1 H$-1,2,3-triazole $\mathbf{1 5}$ $(1 \mathrm{mmol})$ in $95 \%$ ethanol $\left(35 \mathrm{~mL} \mathrm{mmol}^{-1}\right)$, powdered iron $(30 \mathrm{mmol})$ and $\mathrm{CaCl}_{2}(10 \mathrm{mmol})$ were added. The mixture was stirred under reflux for $48 \mathrm{~h}$. Extraction was performed with ethyl acetate and the organic phase was dried over anhydrous $\mathrm{MgSO}_{4}$. The solvent was removed under vacuum. There was no need for purification, and the product was obtained as yellow crystals in $95 \%$ yield. mp $88{ }^{\circ} \mathrm{C}$; IR (KBr) v / cm ${ }^{-1} 3157,3096,2965-2861,1596$, 1523, 1338, 1231, 1037, 849, 748; 'H NMR (300 MHz, $\left.\mathrm{CDCl}_{3}\right) \delta 1.29\left(\mathrm{~s}, 6 \mathrm{H}, 2 \mathrm{CH}_{3}\right), 1.33(\mathrm{~s}, 6 \mathrm{H}), 1.70(\mathrm{~s}, 4 \mathrm{H})$, 6.79 (d, 2H, J $8.8 \mathrm{~Hz}, \mathrm{Ar}-\mathrm{H}), 7.36$ (d, 1H, J 8.1 Hz, Ar-H), 7.52 (d, 2H, $J 8.7 \mathrm{~Hz}, \mathrm{Ar}-\mathrm{H}), 7.57$ (dd, $1 \mathrm{H}, J 8.1,1.8 \mathrm{~Hz}$, Ar-H), 7.85 (d, 1H, J 1.8 Hz, Ar-H), 8.01 (s, 1H, *Tr-H); ${ }^{13} \mathrm{C} \mathrm{NMR}\left(75 \mathrm{MHz}, \mathrm{CDCl}_{3}\right) \delta 31.82,31.85,34.27,34.40$, 35.01, 35.13, 115.30, 117.47, 122.27, 123.20, 123.97, 127.11, 127.66, 128.80, 145.19, 145.51, 147.00, 148.30. HRMS (ESI+) $m / z$ calcd. for $\mathrm{C}_{22} \mathrm{H}_{26} \mathrm{~N}_{4}: 347.2235$; found: 347.2130. *Tr: triazole hydrogen.

Ethyl 4-(4-(5,5,8,8-tetramethyl-5,6,7,8-tetrahydronaphthalen-2-yl)-1 $H$-1,2,3-triazol-1-yl)benzoate (29a)

The product 29a was purified by flash chromatography on silica gel using a hexane/ethyl acetate (98:2) solution as the mobile phase, which furnished the product as yellow crystals in $82 \%$ yield. mp $155^{\circ} \mathrm{C}$; IR $(\mathrm{KBr}) \mathrm{v} / \mathrm{cm}^{-1} 3149$, 3070, 2962-2863, 1720, 1608, 1517, 1484, 1415, 1392, 1274, 1222, 1106, 1029, 844, 769, 690; ' $\mathrm{H}$ NMR (300 MHz, $\left.\mathrm{CDCl}_{3}\right) \delta 1.30\left(\mathrm{~s}, 6 \mathrm{H}, 2 \mathrm{CH}_{3}\right), 1.34\left(\mathrm{~s}, 6 \mathrm{H}, 2 \mathrm{CH}_{3}\right), 1.41$ (t, $\left.3 \mathrm{H}, J 7.2 \mathrm{~Hz}, \mathrm{CH}_{3}\right), 1.71\left(\mathrm{~s}, 4 \mathrm{H}, 2 \mathrm{CH}_{2}\right), 4.41(\mathrm{q}, 2 \mathrm{H}$, $\left.J 7.2 \mathrm{~Hz}, \mathrm{CH}_{2}\right), 7.38(\mathrm{~d}, 1 \mathrm{H}, J 8.2 \mathrm{~Hz}, \mathrm{Ar}-\mathrm{H}), 7.60(\mathrm{dd}, 1 \mathrm{H}$, $J$ 8.2, $1.8 \mathrm{~Hz}, \mathrm{Ar}-\mathrm{H}), 7.87$ (d, 1H, J 1.8 Hz, Ar-H), 7.89 (d,
2H, J $8.8 \mathrm{~Hz}, \mathrm{Ar}-\mathrm{H}), 8.21$ (d, 2H, J $8.8 \mathrm{~Hz}, \mathrm{Ar}-\mathrm{H}), 8.21$ (s, $1 \mathrm{H}, * \mathrm{Tr}-\mathrm{H}) ;{ }^{13} \mathrm{C}$ NMR $\left(75 \mathrm{MHz}, \mathrm{CDCl}_{3}\right) \delta 14.31,31.80$, $31.86,34.32$, 34.42, 34.98, 35.10, 61.43, 116.86, 119.77, $123.29,124.12,127.08,127.23,130.46,131.30,140.12$, 145.67, 145.69, 149.11, 165.48. HRMS (ESI+) $\mathrm{m} / \mathrm{z}$ calcd. for $\mathrm{C}_{25} \mathrm{H}_{29} \mathrm{~N}_{3} \mathrm{O}_{2}[\mathrm{M}+\mathrm{H}]^{+}$: 404.2338; found: 404.2346. $* \mathrm{Tr}$ : triazole hydrogen.

Ethyl 3-(4-(5,5,8,8-tetramethyl-5,6,7,8-tetrahydronaphthalen-2-yl)-1H-1,2,3-triazol-1-yl)benzoate (29b)

The product 29b was purified by crystallization from hexane and was obtained as white crystals in $89 \%$ yield. mp $146{ }^{\circ} \mathrm{C}$; IR (KBr) v / $\mathrm{cm}^{-1} 3145,2989-2863,1708$, 1590, 1481, 1363, 1278, 1241, 1186, 1122, 1035, 892, 759; ${ }^{1} \mathrm{H} \mathrm{NMR}\left(300 \mathrm{MHz}, \mathrm{CDCl}_{3}\right) \delta 1.30$ (s, 6H, 2CH $\left.\mathrm{CH}_{3}\right), 1.35$ (s, $\left.6 \mathrm{H}, 2 \mathrm{CH}_{3}\right), 1.42\left(\mathrm{t}, 3 \mathrm{H}, J 7.0 \mathrm{~Hz}, \mathrm{CH}_{2}\right), 1.71\left(\mathrm{~s}, 4 \mathrm{H}, 2 \mathrm{CH}_{2}\right)$, 4.43 (q, 2H, J 7.0 Hz, CH $)_{2}, 7.39$ (d, $\left.1 \mathrm{H}, J 8.2 \mathrm{~Hz}, \mathrm{Ar}-\mathrm{H}\right)$, $7.63(\mathrm{~m}, 2 \mathrm{H}, \mathrm{Ar}-\mathrm{H}), 7.87$ (d, 1H, J $1.8 \mathrm{~Hz}, \mathrm{Ar}-\mathrm{H}), 8.10$ (m, $2 \mathrm{H}, \mathrm{Ar}-\mathrm{H}), 8.22(\mathrm{~s}, 1 \mathrm{H}, * \mathrm{Tr}-\mathrm{H}), 8.38(\mathrm{dd}, 1 \mathrm{H}, J 8.1,1.7 \mathrm{~Hz}$, $\mathrm{Ar}-\mathrm{H}) ;{ }^{13} \mathrm{C}$ NMR (75 MHz, $\left.\mathrm{CDCl}_{3}\right) \delta 14.32,31.81,31.86$, 34.32, 34.42, 34.99, 35.10, 61.66, 117.15, 120.99, 123.27, 124.09, 124.69, 127.22, 129.49, 129.98, 132.22, 137.27, 145.59, 145.64, 149.01, 165.42. HRMS (ESI+) $\mathrm{m} / \mathrm{z}$ calcd. for $\mathrm{C}_{25} \mathrm{H}_{29} \mathrm{~N}_{3} \mathrm{O}_{2}[\mathrm{M}+\mathrm{H}]^{+}$: 404.2338; found: 404.2348. *Tr: triazole hydrogen.

Ethyl 3-chloro-4-(4-(5,5,8,8-tetramethyl-5,6,7,8-tetrahydronaphthalen-2-yl)-1 H-1,2,3-triazol-1-yl)benzoate (29c)

The product 29c was purified by crystallization from hexane and was obtained as white crystals in $80 \%$ yield. mp $121{ }^{\circ} \mathrm{C}$; IR (KBr) v / cm-1 3143, 3056, 2969-2863, 1716, 1616, 1502, 1446, 1363, 1268, 1105, 1039, 771; ${ }^{1} \mathrm{H} \mathrm{NMR}\left(300 \mathrm{MHz}, \mathrm{CDCl}_{3}\right) \delta 1.30\left(\mathrm{~s}, 6 \mathrm{H}, 2 \mathrm{CH}_{2}\right), 1.34$ (s, $\left.6 \mathrm{H}, 2 \mathrm{CH}_{2}\right), 1.42\left(\mathrm{t}, 3 \mathrm{H}, J 7.1 \mathrm{~Hz}, \mathrm{CH}_{3}\right), 1.71\left(\mathrm{~s}, 4 \mathrm{H}, 2 \mathrm{CH}_{2}\right)$, 4.42 (q, 2H, J 7.2 Hz, $\left.\mathrm{CH}_{2}\right), 7.38$ (d, 1H, J $\left.8.1 \mathrm{~Hz}, \mathrm{Ar}-\mathrm{H}\right)$, 7.59 (dd, $1 \mathrm{H}, J 8.1,1.8 \mathrm{~Hz}, \mathrm{Ar}-\mathrm{H}), 7.80(\mathrm{~d}, 1 \mathrm{H}, J 8.3 \mathrm{~Hz}$, Ar-H), 7.89 (d, 1H, J 1.7 Hz, Ar-H), 8.10 (dd, 1H, J 8.3, $1.8 \mathrm{~Hz}, \mathrm{Ar}-\mathrm{H}), 8.24$ (s, 1H, *Tr-H), 8.25 (d, 1H, J $1.6 \mathrm{~Hz}$, $\mathrm{Ar}-\mathrm{H}) ;{ }^{13} \mathrm{C}$ NMR $\left(75 \mathrm{MHz}, \mathrm{CDCl}_{3}\right) \delta 14.26,31.81,31.85$, $34.31,34.42,34.98,35.10,61.95,120.94,123.33,124.12$, 127.07, 127.22, 127.50, 128.12, 129.03, 132.07, 132.55, 138.14, 145.62, 145.68, 148.22, 164.36. HRMS (ESI+) $\mathrm{m} / z$ calcd. for $\mathrm{C}_{25} \mathrm{H}_{28} \mathrm{ClN}_{3} \mathrm{O}_{2}[\mathrm{M}+\mathrm{H}]^{+}: 438.1948$; found: 438.1939. *Tr: triazole hydrogen.

Ethyl 4-(1-(5,5,8,8-tetramethyl-5,6,7,8-tetrahydronaphthalen-2-yl)-1H-1,2,3-triazol-4-yl)benzoate (36)

The product was purified by crystallization in hexane, providing $\mathbf{3 6}$ as yellow crystals in $85 \%$ yield. $\mathrm{mp} 155^{\circ} \mathrm{C}$; $\mathrm{IR}(\mathrm{KBr}) v / \mathrm{cm}^{-1} 3143,3056,2969-2863,1716,1616,1502$, 1446, 1363, 1268, 1105, 1039, 771; ${ }^{1} \mathrm{H}$ NMR (300 MHz, 
$\left.\mathrm{CDCl}_{3}\right) \delta 1.31\left(\mathrm{~s}, 6 \mathrm{H}, 2 \mathrm{CH}_{3}\right), 1.34\left(\mathrm{~s}, 6 \mathrm{H}, 2 \mathrm{CH}_{3}\right), 1.40$ (t, $\left.3 \mathrm{H}, J 6.0 \mathrm{~Hz}, \mathrm{CH}_{3}\right), 1.73$ (s, 4H, 2CH $), 4.39$ (q, $2 \mathrm{H}$, $\left.J 6.0 \mathrm{~Hz}, \mathrm{CH}_{2}\right), 7.46(\mathrm{~m}, 2 \mathrm{H}), 7.68(\mathrm{~s}, 1 \mathrm{H}), 7.98(\mathrm{~d}, 2 \mathrm{H}$, $J 8.4 \mathrm{~Hz}, \mathrm{Ar}-\mathrm{H}), 8.13$ (d, 2H, J $8.4 \mathrm{~Hz}, \mathrm{Ar}-\mathrm{H}), 8.20$ (s, 1H, $* \mathrm{Tr}-\mathrm{H}) ;{ }^{13} \mathrm{C}$ NMR $\left(75 \mathrm{MHz}, \mathrm{CDCl}_{3}\right) \delta 14.36,31.80,34.37$, $34.69,34.76,34.79,61.07,118.07,118.92,125.54,128.11$, 130.07, 130.23, 134.64, 146.25, 147.05, 166.32. HRMS (ESI+) $\mathrm{m} / z$ calcd. for $\mathrm{C}_{25} \mathrm{H}_{29} \mathrm{~N}_{3} \mathrm{O}_{2}[\mathrm{M}+\mathrm{H}]^{+}:$404.2338; found: $404.2340 . * \operatorname{Tr}$ : triazole hydrogen.

General procedure for the preparation of acid triazole analogues 7-9, 17

To a solution of 29a-c or $\mathbf{3 6}(1 \mathrm{mmol})$ in ethanol $96 \%$ $\left(7 \mathrm{~mL} \mathrm{mmol}^{-1}\right), \mathrm{NaOH}(18.75 \mathrm{mmol})$ was added. The mixture was stirred at room temperature for $24 \mathrm{~h}$. To the final solution, $37 \% \mathrm{HCl}$ was added until $\mathrm{pH}=2$. Then the solution was extracted with ethyl acetate. The organic phase was dried over anhydrous $\mathrm{MgSO}_{4}$, and the solvent was then removed under vacuum. The products were purified by crystallization from hexane/ethyl acetate (70:30).

4-(4-(5,5,8,8-Tetramethyl-5,6,7,8-tetrahydro-naphtha-len2-yl)-1 H-1,2,3-triazol-1-yl)benzoic acid (7)

The product 7 was obtained as white crystals in $95 \%$ yield. mp $278{ }^{\circ} \mathrm{C}$; IR (KBr) v / cm ${ }^{-1} 3900-3500,2961-2924$, 1699-1608, 1558-1410, 1275, 1037, 978, 860, 806, 772; ${ }^{1} \mathrm{H}$ NMR (300 MHz, DMSO- $\left.d_{6}\right) \delta 1.27\left(\mathrm{~s}, 6 \mathrm{H}, 2 \mathrm{CH}_{3}\right), 1.32(\mathrm{~s}$, $\left.6 \mathrm{H}, 2 \mathrm{CH}_{3}\right), 1.67$ (s, 4H, 2CH$\left.{ }_{2}\right), 7.44$ (d, 1H, J 8.4 Hz, Ar-H), 7.70 (dd, 1H, J 8.4, 1.4 Hz, Ar-H), 7.89 (d, 1H, J 1.4 Hz, Ar-H), 8.11 (d, 2H, J 8.7 Hz, Ar-H), 8.18 (d, 2H, J 8.7 Hz, Ar-H), 9.43 (s, 1H, *Tr-H), 13.33 (s, 1H, OH); ${ }^{13} \mathrm{C}$ NMR $\left(75 \mathrm{MHz}, \mathrm{DMSO}-d_{6}\right) \delta 31.96,32.07,34.38,34.48,34.97$, $35.02,119.68,120.03,123.22,123.94,127.54,127.67$, 131.59, 140.02, 145.24, 145.51, 148.38, 167.03. HRMS (ESI+) $m / z$ calcd. for $\mathrm{C}_{23} \mathrm{H}_{25} \mathrm{~N}_{3} \mathrm{O}_{2}[\mathrm{M}+\mathrm{H}]^{+}: 376.2025$; found: 376.2029. Calcd. for $\mathrm{C}_{23} \mathrm{H}_{25} \mathrm{~N}_{3} \mathrm{O}_{2}[\mathrm{M}+\mathrm{Na}]^{+}$: 398.1845; found: 398.1849 . ${ }^{*} \mathrm{Tr}$ : triazole hydrogen.

3-(4-(5,5,8,8-Tetramethyl-5,6,7,8-tetrahydronaphtha-len2-yl)-1H-1,2,3-triazol-1-yl)benzoic acid (8)

The product 8 was obtained as white crystals in $78 \%$ yield. mp $187{ }^{\circ} \mathrm{C}$; IR ( $\left.\mathrm{KBr}\right) \mathrm{v} / \mathrm{cm}^{-1} 3426,2958-2859$, 2667, 2572, 1737, 1710, 1691, 1594, 1465, 1363, 1311, $1245,1230,1105,1054,1049,900,829,754,705 ;{ }^{1} \mathrm{H}$ NMR $\left(300 \mathrm{MHz}, \mathrm{CDCl}_{3}\right) \delta 1.30\left(\mathrm{~s}, 6 \mathrm{H}, 2 \mathrm{CH}_{3}\right), 1.35(\mathrm{~s}, 6 \mathrm{H}$, $\left.2 \mathrm{CH}_{3}\right), 1.71$ (s, 4H, 2CH ), 7.40 (d, $\left.1 \mathrm{H}, J 8.2 \mathrm{~Hz}, \mathrm{Ar}-\mathrm{H}\right)$, 7.66 (m, 2H, Ar-H), 7.89 (d, 1H, J 1.8 Hz, Ar-H), 8.19 (m, $2 \mathrm{H}, \mathrm{Ar}-\mathrm{H}), 8.26$ (s, 1H), 8.46 (s, 1H, $\left.{ }^{*} \mathrm{Tr}-\mathrm{H}\right) ;{ }^{13} \mathrm{C} \mathrm{NMR}$ $\left(75 \mathrm{MHz} \mathrm{CDCl}_{3}\right) \delta 31.81,31.85,34.32,34.43,34.99$, $35.10,117.28,121.46,123.34,124.17,125.52,126.94$,
127.27, 130.19, 131.29, 137.32, 145.69, 147.73, 149.07, 170.00. HRMS (ESI+) $\mathrm{m} / \mathrm{z}$ calcd. for $\mathrm{C}_{23} \mathrm{H}_{25} \mathrm{~N}_{3} \mathrm{O}_{2}[\mathrm{M}+\mathrm{H}]^{+}$: 376.2025; found: 376.2040 . ${ }^{*} \mathrm{Tr}$ : triazole hydrogen.

3-Chloro-4-(4-(5,5,8,8-tetramethyl-5,6,7,8-tetrahydronaphthalen-2-yl)-1 $\mathrm{H}$-1,2,3-triazol-1-yl) benzoic acid (9)

The product 9 was obtained as white crystals in $91 \%$ yield. $\mathrm{mp} 241^{\circ} \mathrm{C}$; IR (KBr) $v / \mathrm{cm}^{-1} 3434,2957-2858,1691$, 1604, 1436-1419, 1288, 1247, 1016; ${ }^{1} \mathrm{H}$ NMR (300 MHz, $\left.\mathrm{CDCl}_{3}\right) \delta 1.30\left(\mathrm{~s}, 6 \mathrm{H}, 2 \mathrm{CH}_{3}\right), 1.35\left(\mathrm{~s}, 6 \mathrm{H}, 2 \mathrm{CH}_{3}\right), 1.71$ (s, 4H, 2 $\left.\mathrm{CH}_{2}\right), 7.40(\mathrm{~d}, 1 \mathrm{H}, J 8.3 \mathrm{~Hz}, \mathrm{Ar}-\mathrm{H}), 7.60$ (dd, 1H, J 8.2, $1.9 \mathrm{~Hz}$, Ar-H), 7.86 (d, 1H, J 8.2 Hz, Ar-H), 7.90 (d, 1H, J 1.7 Hz, Ar-H), 8.18 (dd, 1H, J 8.4, 1.9 Hz, Ar-H), 8.27 (s, 1H, *Tr-H), 8.33 (d, 1H, J 1.8 Hz, Ar-H); ${ }^{13} \mathrm{C}$ NMR $\left(75 \mathrm{MHz}, \mathrm{CDCl}_{3}\right) \delta 31.81,31.85,34.33,34.44$, $34.97,35.09$, 120.99, 123.38, 124.20, 126.85, 127.27, $127.69,128.25,129.69,131.46,132.75,138.79,145.75$, 145.78, 148.30, 168.75. HRMS (ESI+) $\mathrm{m} / \mathrm{z}$ calcd. for $\mathrm{C}_{23} \mathrm{H}_{24} \mathrm{ClN}_{3} \mathrm{O}_{2}[\mathrm{M}+\mathrm{H}]^{+}$: 410.1635; found: 410.1630. *Tr: triazole hydrogen.

4-(1-(5,5,8,8-Tetramethyl-5,6,7,8-tetrahydro-naphtha-len2-yl)-1H-1,2,3-triazol-4-yl)benzoic acid (17)

The product 17 was obtained as white crystals in $93 \%$ yield. mp $219{ }^{\circ} \mathrm{C}$; IR (KBr) $v / \mathrm{cm}^{-1} 3091-2534,2961$, 1694-1614, 1504, 1418, 1313, 1278, 1245, 1181, 1043, 1014, 965, 864, 844, 779, 713, 697; ${ }^{1} \mathrm{H}$ NMR (300 MHz, DMSO- $\left.d_{6}\right) \delta 1.29\left(\mathrm{~s}, 6 \mathrm{H}, 2 \mathrm{CH}_{3}\right), 1.33\left(\mathrm{~s}, 6 \mathrm{H}, 2 \mathrm{CH}_{3}\right), 1.69(\mathrm{~s}$, $\left.4 \mathrm{H}, 2 \mathrm{CH}_{2}\right), 7.58(\mathrm{~d}, 1 \mathrm{H}, J 8.4 \mathrm{~Hz}, \mathrm{Ar}-\mathrm{H}), 7.70$ (dd, 1H, J 8.7, $2.4 \mathrm{~Hz}, \mathrm{Ar}-\mathrm{H}$ ), 7.84 (d, 1H, J $2.4 \mathrm{~Hz}, \mathrm{Ar}-\mathrm{H}$ ), 8.07 (s, 4H, Ar-H), 9.42 (s, $1 \mathrm{H}, * \mathrm{Tr}-\mathrm{H}) ;{ }^{13} \mathrm{C}$ NMR (75 MHz, DMSO- $\left.d_{6}\right)$ $\delta 31.47,34.05,34.42,117.63,117.92,120.75,125.30$, $128.20,130.13,134.36,134.51,145.42,146.26,146.49$, 167.06. HRMS (ESI+) $m / z$ calcd. for $\mathrm{C}_{23} \mathrm{H}_{25} \mathrm{~N}_{3} \mathrm{O}_{2}[\mathrm{M}+\mathrm{H}]^{+}$: 376.2025; found: 376.2019. *Tr: triazole hydrogen.

General procedure for the preparation of acid triazole analogue 18

To a solution of terminal acetylene $27(1 \mathrm{mmol})$ and aryl azide 29a $(1 \mathrm{mmol})$ in DMSO $(3 \mathrm{~mL})$, potassium $t$-butoxide ( $3 \mathrm{mmol}$ ) was added under nitrogen atmosphere. The mixture was stirred for $96 \mathrm{~h}$ at $40{ }^{\circ} \mathrm{C}$. Then, a $37 \%$ $\mathrm{HCl}$ solution was added until $\mathrm{pH}=3$. The reaction mixture was extracted with ethyl acetate and the organic phase was dried over anhydrous $\mathrm{MgSO}_{4}$. The solvent was removed under reduced pressure.

4-(5-(5,5,8,8-Tetramethyl-5,6,7,8-tetrahydronaphtha-len2-yl)-1H-1,2,3-triazol-1-yl)ben-zoic acid (18)

The product 18 was obtained as yellow crystals in $75 \%$ 
yield. IR (KBr) v / cm $\mathrm{cm}^{-1} 2956-2859,1691,1606,1430,1319$, 1292, 1236, 1133, 1008, 970, 863, 825, 774; ${ }^{1} \mathrm{H}$ NMR (300 MHz, DMSO- $\left.d_{6}\right) \delta 0.95\left(6 \mathrm{H}, \mathrm{s}, 2 \mathrm{CH}_{3}\right), 1.20(\mathrm{~s}, 6 \mathrm{H}$, $\left.2 \mathrm{CH}_{3}\right), 1.56\left(\mathrm{~s}, 4 \mathrm{H}, 2 \mathrm{CH}_{2}\right), 7.01(\mathrm{~d}, 1 \mathrm{H}, J 1.5 \mathrm{~Hz}, \mathrm{Ar}-\mathrm{H})$, 7.17 (dd, 1H, J 8.1, $1.8 \mathrm{~Hz}$, Ar-H), 7.38 (d, 1H, J 8.4 Hz, Ar-H), 7.55 (d, 2H, J 8.4Hz, Ar-H), 8.08 (d, 2H, J 8.4Hz, $\mathrm{Ar}-\mathrm{H}), 8.15$ (s, 1H, $* \mathrm{Tr}-\mathrm{H}) ;{ }^{13} \mathrm{C}$ NMR (75 MHz, DMSO- $d_{6}$ ) $\delta 31.53,31.80,34.19,34.39,34.64,34.72,123.43,125.96$, $126.40,126.97,127.67,131.05,132.44,133.40,138.43$, 140.23, 145.27, 146.23, 166.92. HRMS (ESI+) $\mathrm{m} / \mathrm{z}$ calcd. for $\mathrm{C}_{23} \mathrm{H}_{25} \mathrm{~N}_{3} \mathrm{O}_{2}[\mathrm{M}+\mathrm{H}]^{+}:$376.2025; found: 376.2023. *Tr: triazole hydrogen.

\section{Cytotoxicity assay ${ }^{30,48,49}$}

\section{Cell lines}

Six strains of human tumor cells were used: 786-0 (ATCCCRL-1932, kidney carcinoma), HT-29 (ATCC-HTB-38, colon carcinoma), MCF-7 (ATCC-HTB-22, breast adenocarcinoma), PC-3 (PC-3 ATCC-CRL-1435, prostatic adenocarcinoma), HL-60 (ATCC-CCL-240, promyelocytic leukemia) and K-562 (ATCC-CCL-243, chronic myelogenous leukemia). The strains were donated by Professor Dr João Ernesto de Carvalho (CPQBAUNICAMP) and stored under liquid nitrogen. For cytotoxicity assays, the cells were thawed in RPMI-1640 medium supplemented with $10 \%$ fetal calf serum and $1 \%$ streptomycin-penicillin, then maintained in an incubator with $5 \% \mathrm{CO}_{2}$ at $37{ }^{\circ} \mathrm{C}$ in a humid environment for growth.

\section{Sample preparation for analysis}

The samples were prepared by adding DMSO $\left(0.1 \mathrm{~g} \mathrm{~mL}^{-1}\right)$ and then diluted in complete medium to achieve a maximum DMSO concentration of $0.25 \%$.

\section{Cell preparation}

For cell counting, the complete medium was aspirated then $0.5 \mathrm{~mL}$ of EDTA-trypsin (1 mM EDTA, $0.25 \%$ trypsin) in PBS, pH 7.4, was added. The cells were kept in an incubator for 3-5 min. After centrifugation for $4 \mathrm{~min}$ at $1000 \mathrm{rpm}$, trypsin and the medium were discarded and fresh medium was added to obtain a cell suspension. For non-adherent cells the suspension was obtained by centrifugation.

\section{Cytotoxicity activity evaluation}

Cells were placed in 96-well plates (test-plate and T0-plate) $\left(1 \times 10^{4}\right.$ cells plate $^{-1}$ for adherent cells, and $2.5 \times 10^{4}$ cells plate ${ }^{-1}$ for non-adherent cells). After $24 \mathrm{~h}$ at $37{ }^{\circ} \mathrm{C}$ in an atmosphere of $5 \% \mathrm{CO}_{2}$ and $100 \%$ relative humidity, the cells were exposed to 4 different concentrations of each compound: $0.25,2.5,25$ and $250 \mu \mathrm{g} \mathrm{mL}^{-1}$ for $48 \mathrm{~h}$. The adherent cells were then fixed with $100 \mu \mathrm{L}$ of $40 \%$ trichloroacetic acid (TCA), incubated for $30 \mathrm{~min}$ at $4{ }^{\circ} \mathrm{C}$ and colored using sulforhodamine B (SRB) according to the methodology described by Skehan and co-workers. ${ }^{30}$ For non-adherent cells, at the end of the exposure time to the substances, the medium was removed and replaced with $0.2 \mathrm{~mL}$ of fresh MTT solution (final concentration $0.5 \mathrm{mg} \mathrm{mL}^{-1}$ ). The plates were incubated at $37{ }^{\circ} \mathrm{C}$ for $4 \mathrm{~h}$. After the incubation, the medium was removed and insoluble MTT crystals and formazan were dissolved by adding $0.2 \mathrm{~mL}$ of DMSO and the optical densities were read in a spectrophotometric plate reader at $540 \mathrm{~nm}$.

The concentrations of tamibarotene (Sigma-Aldrich ${ }^{\circledR}$ ) used as positive controls were $0.25,2.5,25$ and $250 \mu \mathrm{g} \mathrm{mL}^{-1}$.

For all cells, three absorbance readings were obtained at a wavelength of $540 \mathrm{~nm}$ at time zero (T0) and $48 \mathrm{~h}$ for both the negative controls $(\mathrm{C})$ and the cells treated with the compounds $(\mathrm{T})$. When $\mathrm{C}>\mathrm{T} \geq \mathrm{T} 0$, growth (\%) was determined using the equation $100 \times[(\mathrm{T}-\mathrm{T} 0) / \mathrm{C}-\mathrm{T} 0]$ (cytostatic effect). When $\mathrm{T}<\mathrm{T} 0$, growth $(\%)$ was determined using the equation $100 \times[(\mathrm{T}-\mathrm{T} 0) /(\mathrm{T} 0)]$ (cytocide effect) using Excel 2003/2007. The dose that inhibited growth by $50 \%\left(\mathrm{IC}_{50}\right)$ was determined by nonlinear regression analyses in Origin 6.0 software.

\section{Supplementary Information}

Supplementary data are available free of charge at http://jbcs.sbq.org.br as PDF file.

\section{Acknowledgments}

This study was supported by grants from FUNDECT-MS (Process number 23/200.012/2008 and 23/200.071/2010), PROPP-UFMS, CNPq and CAPES. We thank Dr Janet W. Reid (JWR Associates) for her assistance with English corrections. Special thanks to the Laboratory of Natural Products and Mass Spectrometry (LAPNEM) of the Federal University of Mato Grosso do Sul for the HPLC-DAD-MS/MS analysis.

\section{References}

1. Lyon, France: International Agency for Research on Cancer, 2012. Available at http://globocan.iarc.fr/Pages/fact_sheets_ cancer.aspx, accessed on June 20, 2017.

2. Ali, I.; Wani, W. A.; Saleem, K.; Hsieh, M,-F.; RSC Adv. 2014, 4, 29629; Ali, I.; Wani, W. A.; Saleem, K.; Cancer Ther. 2011, 8, 56; Ali, I.; Ud-din, R.; Saleem, K.; Aboul-Enein, H. Y.; Rather, A.; 
Cancer Ther. 2011, 8, 6; Ali, I.; Wani, W. A.; Saleem, K.; Hsieh, M.; Chem. Pap. 2014, 68, 540; Ali, I.; Wani, W. A.; Haque, A.; Saleem, K.; Future Med. Chem. 2013, 5, 961; Ali, I.; Haque, A.; Saleem, K.; Hsieh, M. F.; Bioorg. Med. Chem. 2013, 21, 3808; Saleem, K.; Wani, W. A.; Haque, A.; Lone, M. N.; Hsieh, M. F.; Jairaipuri, M. A.; Ali, I.; Future Med. Chem. 2013, 5, 135; Ali, I.; Saleem, K.; Wesselinova, D.; Haque, A.; Med. Chem. Res. 2013, 22, 1386; Ali, I.; Wani, W. A.; Saleem, K.; Haque, A.; Anti-Cancer Agents Med. Chem. 2013, 13, 296; Ali, I.; Wani, W. A.; Saleem, K.; Wesselinova, D.; Med. Chem. 2013, 9, 11; Ali, I.; Wani, W. A.; Saleem, K.; Haque, A.; Curr. Drug Ther. 2012, 7, 13.

3. Teng, M.; Duong, T. T.; Klein, E. S.; Pino, M. E.; Chandraratna, R. A. S.; J. Med. Chem. 1996, 39, 3035; Altucci, L.; Leibowitz, M. D.; Ogilvie, K. M.; Lera, A. R.; Gronemeyer, H.; Nat. Rev. Drug Discovery 2007, 6, 793; Lera, A. R.; Bourguet, W.; Altucci, L.; Gronemeyer, H.; Nat. Rev. Drug Discovery 2007, 6,811 .

4. Barnar, J. H.; Collings, J. C.; Whiting, A.; Stefan, A. P.; Marder, T. B.; Chem. Eur. J. 2009, 15, 11430; Álvarez, R.; Vaz, B.; Gronemeyer, H.; De Lera, R. A.; Chem. Rev. 2014, 114, 1; Tanabe, H.; Yasui, T.; Kotani, H.; Nagatsu, A.; Makishima, M.; Amagaya, S.; Inoue, M.; Bioorg. Med. Chem. 2014, 22, 3204.

5. Okuno, M.; Kojima, S.; Matsushima-Nishiwaki, R.; Tsurumi, H.; Muto, Y.; Friedman, S. L.; Moriwaki, H.; Curr. Cancer Drug Targets 2004, 4, 285; Vivat-Hannah, V.; Zusi, F. C.; Mini-Rev. Med. Chem. 2005, 5, 755; Shudo, K.; Fukasawa, H.; Nakagomi, M.; Yamagata, N.; Curr. Alzheimer Res. 2009, 6, 302; Kagechika, H.; Kawachi, E.; Hashimoto, Y.; Himi, T.; Shudo, K.; J. Med. Chem. 1988, 31, 2182; Amano, Y.; Noguchi, M.; Nakagomi, M.; Muratake, H.; Fukasawa, H.; Shudo, K.; Bioorg. Med. Chem. 2013, 21, 4342.

6. Beard, R. L.; Chandraratna, R. A. S. In Retinoids: The Biochemical and Molecular Basis of Vitamin A and Retinoid Action, $1^{\text {st }}$ ed.; Nau, H.; Blaner, W. S., eds; Springer-Verlag: Berlin Heidelberg, 1999, p. 187; Schulman, I. G.; Crombie, D.; Bissonnette, R. P.; Cesario, R.; Roegner, K.; Shao, G.; Heyma, R. A. In Retinoids: The Biochemical and Molecular Basis of Vitamin A and Retinoid Action, $1^{\text {st }}$ ed.; Nau, H.; Blaner, W. S., eds; Springer-Verlag: Berlin Heidelberg, 1999, p. 215.

7. Ostrowski, J.; Roalsivig, T.; Hammer, L.; Marinier, A.; Starret Jr., J. E.; Yu, K. L.; Reczek, P. R.; J. Biol. Chem. 1998, 6, 3490.

8. Kagechika, H.; Shudo, K.; J. Med. Chem. 2005, 48, 5875; Kikuchi, K.; Hibi, S.; Yoshimura, H.; Tokuhara, N.; Tai, K.; Hida, T.; Yamauchi, T.; Nagai, M.; J. Med. Chem. 2000, 43, 409; Kikuchi, K.; Hibi, S.; Yoshimura, H.; Tai, K.; Hida, T.; Tokuhara, N.; Yamauchi, T.; Nagai, M.; Bioorg. Med. Chem. Lett. 2000, 10, 619; Le Maire, A.; Álvarez, S.; Shankaranarayanan, P.; Lera, A. R.; Bourguet, W.; Gronemeyer, H.; Curr. Top. Med. Chem. 2012, 12, 505 .

9. Desphande, A.; Xia, G.; Boerma, L. J.; Vines, K. K.; Atigadda, V. R.; Lobo-Ruppert, S.; Grubbs, J.; Moeinpour, F. L.; Smith,
C. D.; Christov, K.; Brouillette, W. J.; Muccio, D. D.; Bioorg. Med. Chem. 2013, 22, 178.

10. Germain, P.; Kammerer, S.; Pérez, E.; Peluso-Iltis, C.; Tortolani, D.; Zusi, F. C.; Starrett, J.; Lapointe, P.; Daris, J.-P.; Marinier, A.; Lera, A. R.; Rochel, N.; Gronemeyer, H.; EMBO Rep. 2004, $5,877$.

11. Bian, H.; Feng, J.; Xu, W.; Med. Chem. Res. 2013, 22, 175.

12. Nakamura, M.; Hamasaki, T.; Tokitou, M.; Baba, M.; Hashimoto, Y.; Aoyama, H.; Bioorg. Med. Chem. 2009, 17, 4740 .

13. Bian, H.; Feng, J.; Li, M.: Xu, W.; Bioorg. Med. Chem. Lett. 2011, 21, 7025.

14. Ohnnishi, K.; Int. J. Clin. Oncol. 2007, 12, 313.

15. Freitas, L. B. O.; Ruela, F. A.; Pereira, G. R.; Alves, R. B.; Freitas, R. P.; Quim. Nova 2011, 34, 1791; Leoneti-Aragão, V.; Campo, V. L.; Gomes, A. S.; Field, R. A.; Carvalho, I.; Tetrahedron 2010, 66, 9475; Holub, J. M.; Kirshenbaum, K.; Chem. Soc. Rev. 2010, 39, 1325; Appendino, G.; Bacchiega, S.; Minassi, A.; Cascio, M. G.; Petrocellis, L.; Marzo, V.; Angew. Chem., Int. Ed. 2007, 46, 9312; Dheer, D.; Singh, V.; Shankar, R.; Bioorg. Chem. 2017, 71, 30.

16. Ma, L.-Y.; Pang, L.-P.; Wang, B.; Zhang, M.; Hu, B.; Xue, D.Q.; Shao, K.-P.; Eur. J. Med. Chem. 2014, 86, 368.

17. Simoni, D.; Roberti, M.; Invidiata, F. P.; Rondanin, R.; Baruchello, R.; Malagutti, C.; Mazzali, A.; Rossi, M.; Grimaudo, S.; Dusonchet, L.; Meli, M.; Raimondi, M. V.; D'Alessandro, N.; Tolomeo, M.; Bioorg. Med. Chem. Lett. 2000, 10, 2669.

18. Kolb, H. C.; Finn, M. G.; Sharpless, K. B.; Angew. Chem., Int. Ed. 2001, 40, 2004.

19. Miyamoto, Y.; Kalisiak, J.; Korthals, K.; Lauwaet, T.; Cheung, D. Y.; Lozano, R.; Coboa, E. R.; Upcroft, P.; Upcroft, J. A.; Berga, D. E.; Gillin, F. D.; Fokin, V. V.; Sharpless, K. B.; Eckmann, L.; Proc. Natl. Acad. Sci. U. S. A. 2013, 110, 17564; Jardim, G. A. M.; Cruz, E. H. G.; Valença, W. O.; Resende, J. M.; Rodrigues, B. L.; Ramos, D. F.; Oliveira, R. N.; Silva, P. E. A.; Silva Júnior, E. N.; J. Braz. Chem. Soc. 2015, 26, 1013; Silva Júnior, E. N.; Moura, M. A. B. F.; Pinto, A. V.; Pinto, M. C. F. R.; Souza, M. C. B. V.; Araújo, A. J.; Pessoa, C.; CostaLotufo, L. V.; Montenegro, R. C.; Moraes, M. O.; Ferreira, V. F.; Goulart, M. O. F.; J. Braz. Chem. Soc. 2009, 4, 635; Costa, E. C.; Cassamale, T. B.; Carvalho, D. B.; Bosquiroli, L. S. S.; Ojeda, M.; Ximenes, T. V.; Matos, M. F. C.; Kadri, M. C. T.; Baroni, A. C. M.; Arruda, C. C. P.; Molecules 2016, 21, 802.

20. Dabdoub, M. J.; Dabdoub, V. B.; Guerrero Jr., P. G.; Hurtado, G. R.; Tetrahedron Lett. 2012, 53, 5302.

21. Bovonsombat, P.; McNelis, E.; Synthesis 1993, 237; Adhikari, M. V.; Samant, S. D.; Ultrason. Sonochem. 2002, 9, 107.

22. Vuligonda, V.; Thacher, S. M.; Chandraratna, R. A. S.; J. Med. Chem. 2001, 44, 2298; Nazario, C. E. D.; Santana, A. S.; Kawasoko, C. Y.; Carollo, C. A.; Hurtado, G. R.; Viana, L. H.; 
Barbosa, S. L.; Guerrero Jr., P. G.; Marques, F. A.; Dabdoub, V. B.; Dabdoub, M. J.; Baroni, A. C. M.; Tetrahedron Lett. 2011, 54, 4177; Christie, V. B.; Barnard, J. H.; Batsanov, A. S.; Bridgens, C. E.; Cartmell, E. B.; Collings, J. C.; Maltman, D. J.; Redfern, C. P.; Marder, T. B.; Przyborski, S.; Whiting, A.; Org. Biomol. Chem. 2008, 6, 3497.

23. Barral, K.; Moorhouse, A. D.; Moses, J. E.; Org. Lett. 2007, 9 , 1809.

24. Lee, B. Y.; Park, S. R.; Jeon, H. B.; Kim, K. S.; Tetrahedron Lett. 2006, 47, 5105.

25. Simoni, D.; Roberti, M.; Invidiata, F. P.; Rondanin, R.; Baruchello, R.; Malagutti, C.; Mazzali, A.; Rossi, M.; Grimaudo, S.; Capone, F.; Dusonchet, L.; Meli, M.; Raimondi, M. V.; Landino, M.; D’Alessandro, N.; Tolomeo, M.; Arindam, D.; Lu, S.; Benbrook, D. M.; J. Med. Chem. 2001, 44, 2308.

26. Fortin, J. S.; Côté, M.-F.; Lacroix, J.; Desjardins, M.; Petitclerc, E.; C.-Gaudreault, R.; Bioorg. Med. Chem. 2008, 16, 7277; Ohsawa, F.; Yamada, S.; Yakushiji, N.; Shinozaki, R.; Nakayama, M.; Kawata, K.; Hagaya, M.; Kobayashi, T.; Kohara, K.; Furusawa, Y.; Fujiwara, C.; Ohta, Y.; Makishima, M.; Naitou, H.; Tai, A.; Yoshikawa, Y.; Yasui, H.; Kakuta, H.; J. Med. Chem. 2013, 56, 1865.

27. Chandrappa, S.; Vinaya, K.; Ramakrishnapa, T.; Rangappa, K. S.; Synlett 2010, 20, 3019.

28. Feng, K.; Peng, M.-L.; Wang, D.-H.; Zhang, L.-P.; Tung, C.-H.; Wu, L.-Z.; Dalton Trans. 2009, 9794.

29. Kwok, S. W.; Fotsing, J. R.; Fraser, R. J.; Rodionov, V. O.; Fokin, V. V.; Org. Lett. 2010, 12, 4217.

30. Mosmann, T.; J. Immunol. Methods 1983, 65, 55; Freshney, I. R.; Culture of Animal Cells. A Manual of Basic Technique, $5^{\text {th }}$ ed.; Wiley-Liss: New York, USA, 2005; Monks, A.; Scudiero, D.; Skehan, P.; Shoemaker, R.; Paull, K.; Vistica, D.; Hose, C.; Langley, J.; Cronise, P.; Vaigro-Wolff, A.; J. Natl. Cancer Inst. 1991, 83, 757.

31. Jiang, Y.; Li, X.; Wang, X.; Wang, Z.; Zhang, J.; Wu, J.; Xu, W.; Chem. Biol. Drug. Des. 2016, 88, 542.

32. Ciapetti, P.; Giethlen, B. In The Practice of Medicinal Chemistry, $3^{\text {rd }}$ ed.; Wermuth, C. G., ed.; Academic Press: London, 2008, p. 290.

33. Tashima, T.; Kagechika, H.; Tsuji, M.; Fukasawa, H.; Kawachi, E.; Hashimoto, Y.; Shudo, K.; Chem. Pharm. Bull. 1997, 45,
1805; Yamakawa, T.; Kagechika, H.; Kawachi, E.; Hashimoto, Y.; Shudo, K.; J. Med. Chem. 1990, 33, 1430.

34. Liu, S.; Brown, C. W.; Berlin, K. D.; Dhar, A.; Guruswamy, S.; Brown, D.; Gardner, G. J.; Birrer, M. J.; Benbrook, D. M.; J. Med. Chem. 2004, 47, 999.

35. Price, C. J.; Zeits, P. D.; Reibenspies, J. H.; Miller, S. A.; Organometallics 2008, 27, 3722; Zou, Y.; Qin, L.; Ren, X.; Lu, Y.; Li, Y.; Zhou, S. J.; Chem. - Eur. J. 2013, 19, 3504.

36. Held, P.; Heck, M.-P.; Iyer, J.; Gronemeyer, H.; Lebeau, L.; Mioskowski, C.; J. Labelled Compd. Radiopharm. 1997, 39, 501.

37. Garipova, G.; Gautier, A.; Piettre, S. R.; Tetrahedron 2005, 61, 4755; Nakamura, M.; Matsumoto, Y.; Toyama, M.; Baba, M.; Hashimoto, Y.; Chem. Pharm. Bull. 2013, 61, 237.

38. Markert, C.; Bannwarth, W.; Helv. Chim. Acta 2002, 85, 1877.

39. Chandraratna, V.; Chandraratna, T.; J. Med. Chem. 2001, 44, 2298.

40. Schaate, A.; Roy, P.; Preube, T.; Lohmeier, S. J.; Godt, A.; Behrens, P.; Chem. - Eur. J. 2011, 17, 9320.

41. Stoll, A. H.; Knochel, P.; Org. Lett. 2008, 10, 113.

42. Friis, S. D.; Andersen, T. L.; Skrydstrup, T.; Org. Lett. 2013, 15, 1378 .

43. Yang, W.; Xu, L.; Chen, Z.; Zhang, L.; Miao, M.; Ren, H.; Org. Lett. 2013, 15, 1282.

44. Hu, M.; Li, J.; Yao, S. Q.; Org. Lett. 2008, 10, 5529.

45. Chambers, J. M.; Aru, P. H.; Aaron, J. A.; Han, Z.; Christianson, D. W.; Kuzma, N. N.; Dmochowski, I. J.; J. Am. Chem. Soc. 2009, 131, 563.

46. Cassamale, T. B.; Costa, E. C.; Carvalho, D. B.; Cassemiro, N. S.; Tomazela, C. C.; Marques, M. C. S.; Ojeda, M.; Matos, M. F. C.; Albuquerque, S.; Arruda, C. C. P.; Baroni, A. C. M.; J. Braz. Chem. Soc. 2016, 27, 1217.

47. Bruins, J. J.; Rutjes, F. P. J. T.; Van Delft, F. L.; Van Kalkeren, H. A.; Adv. Synth. Catal. 2012, 354, 1417.

48. Mosmann, T.; J. Immunol. Methods 1983, 65, 55.

49. Skehan, P.; Storeng, R.; Scudiero, D.; Monks, A.; Mcmahon, J.; Vistica, D.; Warren, J. T.; Bokesch, H.; Kenney, S.; Boyd, M. R.; J. Natl. Cancer Inst. 1990, 82, 1107.

Submitted: April 6, 2017 Published online: June 27, 2017 